\title{
Going beyond Good Intentions for the Sustainable Conservation of Built Heritage: A Systematic Literature Review
}

\author{
Joana Gonçalves ${ }^{1,2}, * \mathbb{E}$, Ricardo Mateus ${ }^{1} \mathbb{D}$, José Dinis Silvestre ${ }^{3} \mathbb{C}$ and Ana Pereira Roders ${ }^{2}$ \\ 1 Institute for Sustainability and Innovation in Structural Engineering (ISISE), School of Engineering, \\ University of Minho, 4800-058 Guimarães, Portugal; ricardomateus@civil.uminho.pt \\ 2 Faculty of Architecture and the Built Environment, Delft University of Technology, 2033 AP Delft, \\ The Netherlands; a.r.pereira-roders@tudelft.nl \\ 3 CERIS-Instituto Superior Técnico, Universidade de Lisboa, 1000 Lisboa, Portugal; \\ jose.silvestre@tecnico.ulisboa.pt \\ * Correspondence: j.m.goncalves@tudelft.nl
}

Received: 15 September 2020; Accepted: 10 November 2020; Published: 19 November 2020

\begin{abstract}
This research addresses the performance gap between intentions towards a sustainable conservation of built heritage and its actual implementation. Socio-psychological models of human behaviour, such as the theory of planned behaviour (TPB), have been studying this dissonance between intention and behaviour, and allow to recognise latent critical factors. This paper provides a systematic literature review of research publications on the intersection of the topics of human behaviour, heritage, and sustainability. It aims to analyse how the TPB has been used in the field of sustainable conservation of built heritage. The studies are categorised according to the type of heritage, main actors targeted, aims, and methodology. A total of 140 publications were analysed. The results show a recent field of research. In the domain of built heritage conservation, behaviour is commonly addressed as a synonym of performance, targeting the building itself. Most publications relating socio-psychological constructs of behaviour and heritage sustainability can be found in the tourism and hospitality field, focusing on tourists' and residents' behaviours. The review shows that practitioners are still absent from the literature. However, research addressing other stakeholders shows that the theoretical framework can play an important role in the implementation of sustainable conservation practices in the built heritage.
\end{abstract}

Keywords: behavioural intentions; built environment; heritage; sustainability; conservation

\section{Introduction}

The inclusion of heritage on the global agenda for sustainable development [1] has raised awareness for the importance of bridging the concepts of heritage and sustainability. Today, the concept of sustainable conservation can be defined as an extension of sustainable development, recognizing the value of the inheritance from the past for present and future generations [2]. As stated by the Recommendation on the Historic Urban Landscape, heritage conservation is a condition sine qua non for sustainable development [3].

As a driver of sustainable development [4], the benefits of heritage range from improving social cohesion and wellbeing [5] to contributing to local economies as a focus of attractiveness and economic growth [6]. But significant contributions can also be found on the environmental dimension, as heritage is a knowledge capital on how to cope with the environment [7], on circular economy and/or on reduced carbon footprint [8]. 
In the last decades, many studies have focused on the different connections between heritage and environmental sustainability. These studies highlighted the benefits of traditional passive solutions for energy efficiency (e.g., [9-11]), the advantages of natural materials for healthy indoor environments (e.g., [12]), or the effectiveness of resilience strategies to face natural hazards (e.g., [13,14]). Tools to support decision-making have been developed to encourage design decisions to integrate economic aspects, cultural significance, and environmental performance [15-17]. However, despite the information, standards and tools already developed, a common question still emerges in the literature: why are sustainable conservation approaches not more widely implemented in the built heritage field [18-20]?

This research aims at contributing to going beyond good intentions towards the sustainable conservation of the built heritage [21]. It uses a systematic literature review to understand how behavioural sciences, which for long proved the correlation between intention and behaviours [22-27], can support the identification of the main factors that are today undermining the implementation of sustainable conservation practices in the built heritage.

\subsection{Theoretical Framework}

The intention-behaviour gap is addressed in psychology as cognitive dissonance. Sociopsychological models, such as the theory of reasoned action (TRA [28]) and the theory of planned behaviour (TPB [23]), are based on the premise that "the immediate antecedent of behaviour is the person's intention to perform the behaviour" [23]. However, these theories also recognise that intentions and behaviour do not always match, due to low facilitating conditions and to intervening events [25,29]. Understanding these facilitating conditions is essential to design effective interventions, where participants implement their positive intentions, since the gap between intention and behaviour can mainly be attributed to inclined abstainers, meaning persons who intend to act, but fail to implement their intentions [30,31].

According to the Theory of Planned Behavior [22,23], intentions are influenced by three considerations: 1) beliefs about consequences of an action, determining favourable or unfavourable personal evaluations (attitude); 2) beliefs about normative expectations, resulting from external social pressures (subjective norm); and 3) beliefs about factors that may impede performance, or the perceived behavioural control (PBC). Although these aspects may impact the actual performance of intentions, attitudes and subjective norms tend to be moderated by perceived behavioural control, since "participants do not generally intend to perform behaviours they perceive to be outside their control" [30]. Knowledge, ability, resources, availability, opportunity, and cooperation are the main factors affecting the perception of control [30].

To secure intention implementation, "people need to initiate, maintain and close goal pursuit" [27], and challenges may be found in the three steps. According to Pieters and Zeelenberg [32], intention-behaviour inconsistency induces regret in abstainers, as an indicator of a failed decision process. While good intentions alone may not be sufficient to change behaviours, high levels of perceived behavioural control are more likely to be converted to performance [33]. According to Sheeran [30], even if external pressures (i.e., obtaining approval, rewards or punishment from others) have a role in determining intention, self-chosen intentions resulting from personal beliefs are more likely to be successfully implemented. Thus, interventions should be directed to the internal motivations of participants and to increasing the perceived behavioural control, empowering the target group acting on the specific factors that are affecting performance.

The TRA and the later extended TPB define a framework with a limited set of psychological constructs (attitudes, subjective norms, perceptions of control, intentions) that can be used to predict and understand behaviours in multiple domains. While the behaviour itself is domain-specific, and defined in the scope of each specific research, Fishbein and Ajzen [34] suggest that the basic four psychological constructs can be applied, as long as they are defined in a consistent way (focusing the same action and target, in the same context, at the same time). These models to analyse and predict 
behaviours have been frequently used in the scope of health-related behaviours, such as medication, self-examination or nutrition [35-38], and to understand consumers' decisions in market studies [39]. More recently, the scope was broadened to studies on entrepreneurship [31], job search decisions [33], or sustainable consumption patterns $[40,41]$.

In the context of a sustainable built environment, the TPB has been used to profile users according to predictable behaviours, to establish recommendations and policies for planning and design. Sang, Yao, Zhang et al. [42] identified the factors affecting consumers' willingness to buy green-labelled houses. It showed that internal psychological factors play a role side by side with design and government measures for implementation [42]. Du Toit, Wagner and Fletcher [43] profiled householders based on their recycling behaviours and housing type, identifying critical factors behind the practices. Ortiz and Bluyssen [44] profiled home occupants based on their energy consumption patterns, creating a tool that allows interventions to be better tailored to specific user needs.

This paper presents a literature review of studies that use the methodological insights of behavioural sciences to address challenges related to heritage conservation, and more specifically to its sustainability. The main goal is to grow understanding of how the TPB can be applied to promote the implementation of good practices on sustainable conservation of built heritage, going beyond good intentions.

\section{Materials and Methods}

This research follows a systematic literature review methodology [45,46], aiming at answering the question of how the TPB has been used to instigate practitioners' behavioural change in the field of sustainable conservation of built heritage.

Data were searched for on Web of Science bibliographic database, on 16 June 2020, considering the presence of key terms in "all fields." A scoping search on the Web of Science bibliographical database focused on the specific topic of the application of the TPB in the field of heritage and sustainability (heritage AND theory of planned behav* AND sustain*) results in only 14 publications. To attain a more complete picture of the field, the main search uses broader search syntaxes: "heritage AND sustain* AND behav*", "heritage AND sustain* AND intention", and "heritage AND theory of planned behav *". The search operator "**" was used as a wildcard, to search for variations of the word. Given the low quantity of results obtained during the process, no limitations were applied regarding date or type of publication, allowing to understand tendencies on how this issue has been explored in the last decades.

The data extraction was organised in a sequential selection of publications (Figure 1), with different inclusion and exclusion criteria. In the first step, the 1058 results obtained using the search syntaxes were filtered according to scope. Duplicates were eliminated, as well as publications considered out of the scope of this research. Papers were included when they mention "heritage" or semantically related expressions, such as "historical buildings", "monuments", or "cultural value". When the use of the keywords "heritage" and "intention" was found circumstantial and not fundamental (for instance "the intention of the paper is"), papers were also excluded. No requirements were applied to the meaning of "behaviour" at this stage. It resulted in a total of 506 publications, after eliminating duplicates.

In the second step, data were organised and classified in data extraction tables and excluded from further analysis if they were not related to human behaviour, and if they were not published in English.

In the third step, the 140 remaining publications were analysed considering, as key variables, type of heritage; type of stakeholder; aims and methodology. Lastly, 30 studies with clear methodological frameworks related to the TPB or the TRA, behavioural intentions, behavioural change, and decision-makers were analysed in-depth, considering study scale and sample, and conclusions. From these studies, 4 were related to behavioural change, 3 to built heritage, and only 1 focused on decision-makers. 


\section{How has the TRA/TPB been used to instigate practitioners' behavioural change in the field of the Sustainable Conservation of the Built Heritage?}

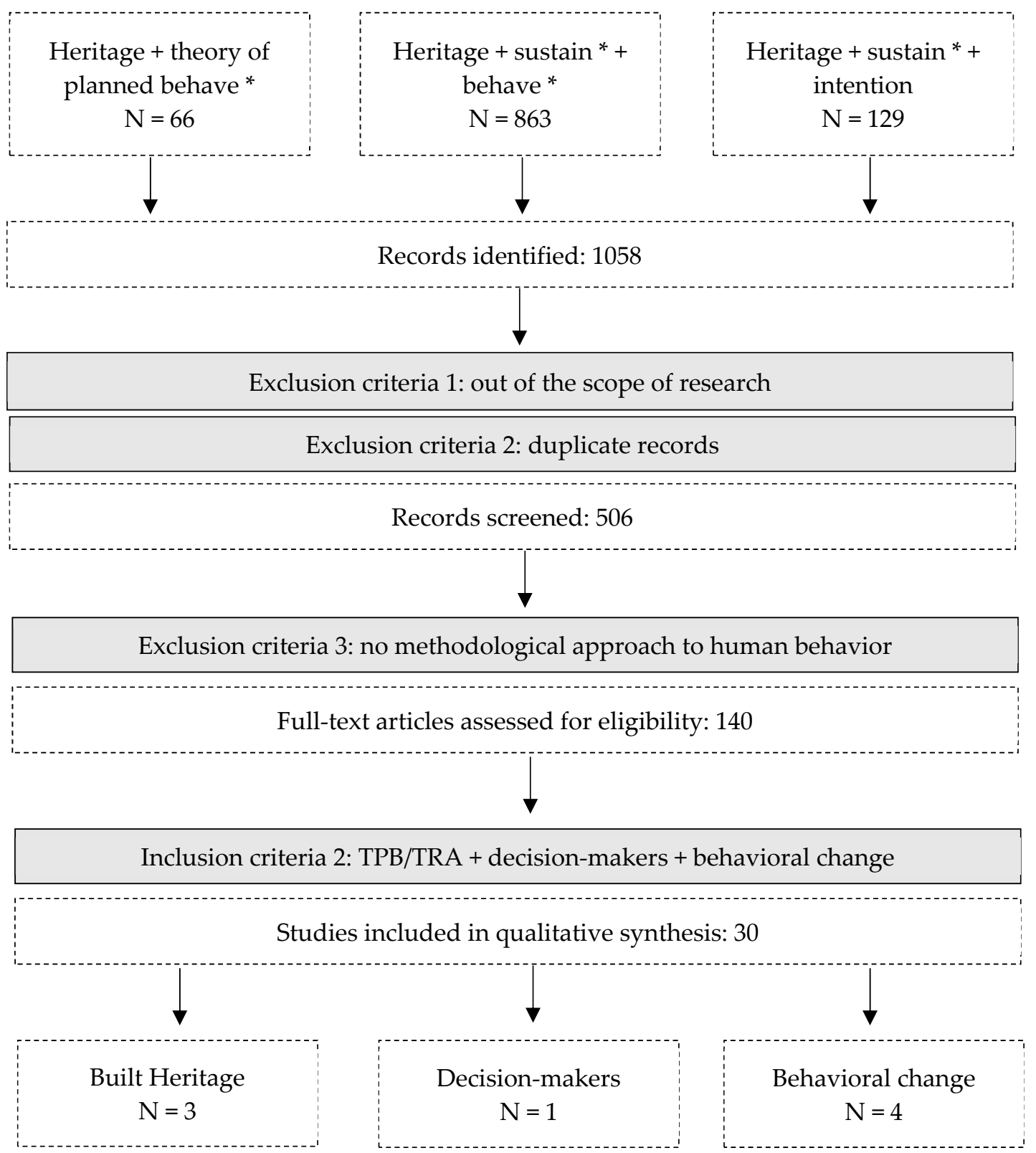

Figure 1. PRISMA flow diagram with inclusion and exclusion criteria for the selection of literature.

\section{Results}

\subsection{General Overview}

From the selected 506 papers, almost a third (154 papers) were related to built heritage. However, only 33 of those refer to human behaviour. In the 121 remaining publications about built heritage, the term behaviour was used to refer to the building's performance: either structural behaviour or hygrothermal and energy behaviour. 
Therefore, building performance in the built heritage context is tackled as: (1) Structural behaviour (representing $44 \%$ of the publications about built heritage) which includes seismic vulnerability assessment of existing buildings (e.g., [47-50]), structural health monitoring (e.g., [51-54]), or mechanical properties of construction materials (e.g., [55-59]). (2) Hygrothermal and energy performance of buildings (representing a quarter of the publications on built heritage); integrates publications about bioclimatic strategies (e.g., [60,61]), strategies for energy renovation (e.g., [62-65]), or hygrothermal performance of traditional building systems (e.g., [66-69]).

In parallel with the use of the concept of behaviour as performance, the findings also show the use of the concept as background or factor. In 10\% of the cases, human behaviour is mentioned as the publication background, referring, for instance, to past behaviours of a community in the scope of archaeological research [70]. In 19\% of the cases, behaviour is recognised as a factor that can influence the findings. As examples, Mutani et al. mention that "energy models should take into account also the urban morphology, people's behaviour, social and economic conditions, local and national regulation, and the use of outdoor public spaces" [71]; while Galvin et al. state the need to consider "consumer behaviour issues such as the rebound effect" for sustainable thermal retrofit of existing buildings [72]. However, the topic is not explicitly addressed in those studies, highlighting the importance of further research from a behavioural perspective.

The findings show that this is a recent field of research. Around $40 \%$ of the results were published since 2018; 75\% after 2015. Publications before 2008 are only residual (less than 4\%). There is a great geographic diversity in the origins of the publications, with Italy (15\%) and China $(10 \%)$ leading the results. However, most publications (63\%) from southern Europe (Portugal, Spain, and Italy) use behaviour to refer to the building's performance, leaving China and Australia as the major contributors in the topics of human behaviour, heritage, and sustainability. In the same way, the exclusion of papers that consider behaviour as performance results in a significant reduction of the papers in the research field of engineering, and building technology and construction, falling from $32 \%$ to only $9 \%$ of the overall selection. The selected publications are concentrated on the research fields of social sciences $(39 \%)$, science and technology $(30 \%)$, and environmental sciences and ecology $(27 \%)$. A resulting set of 140 publications with a methodological approach to human behaviour in the scope of sustainable heritage was further analysed in the following section.

\subsection{Methodological Approaches to Human Behaviour}

\subsubsection{Aims}

By analysing the aims of the studies, a total of 23 common themes emerged, showing the predominant focus of studies in certain actors and objectives, as shown in Table 1.

Almost a quarter of the publications (22\%) are related with behavioural intentions: either measuring factors affecting tourists' cultural intentions (e.g., [73-76]) and intention to revisit a destination (e.g., [77-80]), the residents' intention to participate in heritage tourism (e.g., [81,82]), or the business intentions of tourist operators and investors (e.g., [83]). However, no studies were found directly targeting the cognitive dissonance between intentions and behaviours, and the factors affecting this gap, even if $6 \%$ of the publications refer to behavioural change [84-87].

Satisfaction is a common construct in the literature, used to assess visitors' experiences in the scope of marketing management on touristic destinations (e.g., [88-91]). Willingness-to-pay is used to analyse residents' and visitors' disposition to support the costs of the preservation of cultural and natural heritage, allowing to identify and prioritise values (e.g., [92-96]). The publications referring to segmentation studies aim at typifying profiles of tourists (e.g., [97-100]) or local communities [101] according to behavioural characteristics, such as motivation to visit heritage sites [101] or awareness of the World Heritage brand [102], for instance. 
Table 1. Thematic analysis of the main constructs and main aims identified in the literature

\begin{tabular}{|c|c|c|c|}
\hline Actors & Main Construct & Aim & $\%$ \\
\hline \multirow{8}{*}{ Residents $(n=38)$} & Attitudes towards tourism & $\begin{array}{l}\text { Measure residents' attitudes towards } \\
\text { heritage tourism }\end{array}$ & $6 \%$ \\
\hline & Intentions towards tourism & $\begin{array}{l}\text { Measure residents' intentions to } \\
\text { support tourism }\end{array}$ & $6 \%$ \\
\hline & Value recognition & $\begin{array}{l}\text { Measure residents' awareness of } \\
\text { heritage values }\end{array}$ & $5 \%$ \\
\hline & Pro-environmental attitudes & $\begin{array}{l}\text { Measure residents' } \\
\text { pro-environmental attitudes }\end{array}$ & $3 \%$ \\
\hline & Conservation behaviours & $\begin{array}{l}\text { Identify factors affecting the conservation of } \\
\text { natural and cultural heritage }\end{array}$ & $3 \%$ \\
\hline & Willingness to pay & $\begin{array}{l}\text { Residents' willingness to pay for the } \\
\text { preservation of values }\end{array}$ & $2 \%$ \\
\hline & Segmentation & $\begin{array}{l}\text { Profile residents based on } \\
\text { behavioural characteristics }\end{array}$ & $1 \%$ \\
\hline & Integration behaviour & $\begin{array}{l}\text { Measure residents' urban integration and } \\
\text { willingness to relocate }\end{array}$ & $1 \%$ \\
\hline \multirow{11}{*}{ Tourists $(n=79)$} & Satisfaction & $\begin{array}{l}\text { Measure tourists' satisfaction in } \\
\text { heritage destinations }\end{array}$ & $11 \%$ \\
\hline & Spatial behaviour & Identify travel and movement patterns & $7 \%$ \\
\hline & Behavioural intentions & $\begin{array}{l}\text { Identify factors affecting tourists' } \\
\text { behavioural intentions }\end{array}$ & $6 \%$ \\
\hline & Willingness to pay & $\begin{array}{l}\text { Measure tourists' willingness to pay for the } \\
\text { preservation of values }\end{array}$ & $5 \%$ \\
\hline & Segmentation & $\begin{array}{l}\text { Profile tourists based on } \\
\text { behavioural characteristics }\end{array}$ & $5 \%$ \\
\hline & Perceptions & $\begin{array}{l}\text { Assess tourists' perceptions of } \\
\text { heritage experiences }\end{array}$ & $5 \%$ \\
\hline & Intention to revisit & Measure tourists' intention to revisit & $5 \%$ \\
\hline & Attitudes & $\begin{array}{l}\text { Assess tourists' attitudes towards } \\
\text { heritage destinations }\end{array}$ & $4 \%$ \\
\hline & Behavioural change & $\begin{array}{l}\text { Persuasive communication and information } \\
\text { to change tourist behaviour }\end{array}$ & $4 \%$ \\
\hline & Consumption behaviour & Measure factors affecting consumer decisions & $3 \%$ \\
\hline & Well-being & $\begin{array}{l}\text { Measure the effect of visit in tourists' } \\
\text { psychological wellbeing }\end{array}$ & $2 \%$ \\
\hline \multirow{3}{*}{ Business $(n=9)$} & Business intentions & Factors affecting entrepreneurial behaviour & $5 \%$ \\
\hline & Behavioural change & Increase pro-environmental behaviours & $2 \%$ \\
\hline & Perceptions & Measure perceptions of investors & $1 \%$ \\
\hline Decision-Makers & Decision-making behaviour & Factors affecting decision-making behaviour & $2 \%$ \\
\hline Others & & & $3 \%$ \\
\hline
\end{tabular}

\subsubsection{Actors and Type of Heritage}

Considering the actors targeted in the studies, four main groups emerge: (1) tourists and visitors; (2) residents and local communities; (3) business owners, tourist operators, and staff; (4) decision-makers, public authorities, and government.

The majority $(56 \%)$ of the publications focus on tourist perspectives, as presented in Table 2. In this group, one-third of the results are related to natural heritage, reflecting the predominance of studies in the field of pro-environmental behaviours, measuring, for instance, tourists' perspectives on environment and their perceived responsibility (e.g., [103-105]). Additionally, in the scope of natural heritage, several studies analyse the effects of visitation in mental and physical well-being (e.g., $[87,106,107])$. A significant number of publications $(15 \%)$ refer to heritage as a destination. In these cases, research is mostly related to factors affecting travel behaviours and intention to revisit, such as authenticity (e.g., $[108,109])$, visiting experience and satisfaction (e.g., [110,111]), or place attachment (e.g., [76]). For instance, Ramkinsson [112] analysed how perceived authenticity-a place's cultural and natural characteristics that are interpreted as genuine-affects tourists' intentions to consume cultural attractions. The author also relates the concepts of place attachment (emotional bonds emerging from 
interactions between people and settings of a place) and satisfaction (judgement of the perceived quality of a setting considering physical characteristics and settings) with tourists' intentions towards heritage destinations.

Table 2. Literature referring to tourists and visitors.

\begin{tabular}{|c|c|c|c|c|c|}
\hline Author, Year & Ref. & Country & Heritage & Actors & Theoretical Framework \\
\hline $\begin{array}{l}\text { Bae, Jung, Moorhouse, Suh, } \\
\text { and Kwon, } 2020\end{array}$ & [113] & South Korea & (destinations) & visitors & brand equity theory \\
\hline Cappa, Rosso, and Capaldo, 2020 & [114] & Italy & (museums) & visitors & visitor-sensing; spatial analysis \\
\hline Piramanayagam et al., 2020 & {$[79]$} & India & $\begin{array}{l}\text { archaeological } \\
\text { (WHS) }\end{array}$ & visitors & behavioural intention \\
\hline Menor-Campos et al., 2020 & [101] & Spain & urban (WHS) & tourists & behaviour segmentation \\
\hline $\begin{array}{l}\text { Chow, Ma, Wong, Lam, } \\
\text { and Cheung, } 2019\end{array}$ & {$[115]$} & China & natural & tourists & behavioural intention \\
\hline (Cong et al., 2019) & [92] & China & natural & tourists & WTP; choice experiment method \\
\hline Curnock et al., 2019 & [116] & Australia & natural (WHS) & tourists & theory of emotions \\
\hline Jin et al., 2019 & [95] & South Korea & sites (WHS) & tourists & $\begin{array}{l}\text { contingent valuation method; } \\
\text { stakeholder theory; WTP }\end{array}$ \\
\hline $\begin{array}{l}\text { Jurado-Rivas and } \\
\text { Sánchez-Rivero, } 2019\end{array}$ & {$[96]$} & Spain & urban (WHS) & tourists & WTP; behaviour segmentation \\
\hline Huang et al., 2019 & [107] & China & intangible; natural & tourists & PERMA model \\
\hline Kunasegaran et al., 2019 & [110] & Malaysia & intangible & tourists & Urry's tourist gaze theory \\
\hline Khairi, Ismail, and Syed Jaafar, 2019 & [117] & Malaysia & urban (WHS) & tourists & theory of tourism consumption \\
\hline $\begin{array}{l}\text { Medina-Viruel, López-Guzmán, } \\
\text { Gálvez, and Jara-Alba, } 2019\end{array}$ & [118] & Spain & urban (WHS) & tourists & Crompton's motivational theory \\
\hline Nian et al., 2019 & [74] & China & natural (WHS) & tourists & value-belief-norm; ТPB \\
\hline $\begin{array}{l}\text { Weber, Groulx, Lemieux, Scott, } \\
\text { and Dawson, } 2019\end{array}$ & [119] & Canada & natural (WHS) & tourists & (unclear) \\
\hline Woyo and Woyo, 2019 & [120] & Namibia & (destination) & tourists & (unclear) \\
\hline $\begin{array}{l}\text { Wu, Shen, Wang, Hou, } \\
\text { and Yang, } 2019\end{array}$ & [121] & China & (museum) & tourists & subjective well-being \\
\hline Zhang and Wang, 2019 & [80] & China & urban (WHS) & tourists & planning behaviour theory/TPB \\
\hline Scuttari, Orsi, and Bassani, 2019 & [122] & Italy & natural (WHS) & visitors & (unclear) \\
\hline $\begin{array}{l}\text { Alazaizeh, Jamaliah, Mgonja, } \\
\text { and Ababneh, } 2019\end{array}$ & [123] & Jordan & $\begin{array}{l}\text { archaeological } \\
\text { (WHS) }\end{array}$ & visitors & attribution theory \\
\hline Bergel and Brock, 2019 & [77] & Germany & natural (WHS) & visitors & customer engagement; TPB \\
\hline Song and Kim, 2019 & [124] & South Korea & built (WHS) & visitors & value-attitude-behaviour hierarchy \\
\hline Adie et al., 2018 & {$[102]$} & $\begin{array}{l}\text { United } \\
\text { Kingdom }\end{array}$ & built (WHS) & tourists & Branding; behaviour segmentation \\
\hline Borges, Vieira, and Gomes, 2018 & [125] & Portugal & urban (WHS) & tourists & (unclear) \\
\hline $\begin{array}{l}\text { Cheng, Wang, Cao, Zhang, } \\
\text { and Bai, } 2018\end{array}$ & [126] & China & sites & tourists & service quality \\
\hline Gao et al., 2018 & [103] & China & natural (WHS) & tourists & generational cohort theory \\
\hline Kim et al., 2018 & [78] & USA & natural (WHS) & tourists & behavioural intention \\
\hline Lee and Phau, 2018 & {$[88]$} & Australia & urban & tourists & cognitive appraisal theory \\
\hline Mehmood, Liang, and Gu, 2018 & [127] & China & natural (WHS) & tourists & word-of-mouth; behavioral intention \\
\hline $\begin{array}{l}\text { Prayag, Suntikul, } \\
\text { and Agyeiwaah, } 2018\end{array}$ & [128] & China & intangible & tourists & cognitive-affective-behaviour system \\
\hline Kastenholz et al., 2018 & [100] & Portugal & (destination) & visitors & behavior segmentation \\
\hline Lin and Liu, 2018 & [108] & China & (destination) & visitors & existential authenticity \\
\hline $\begin{array}{l}\text { Martinez-Garcia, Raya-Vilchez, } \\
\text { and Galí, } 2018\end{array}$ & [129] & Spain & (destination) & visitors & attraction theory \\
\hline Weaver et al., 2018 & [130] & China & (museum) & visitors & Social representations theory \\
\hline Muñoz-Fernández et al., 2018 & [91] & Spain & urban (WHS) & tourists & (unclear) \\
\hline Wang, Yang, Han, and Shi, 2017 & [131] & China & natural (WHS) & tourists & (unclear) \\
\hline Gálvez et al., 2017 & [99] & Spain & intangible & tourists & behaviour segmentation \\
\hline Gao et al., 2017 & [104] & China & natural (WHS) & tourists & Norm-activation theory \\
\hline Su, Hsu, and Swanson, 2017 & [132] & China & natural (WHS) & tourists & (unclear) \\
\hline Soliman and Abou-Shouk, 2017 & [133] & Egypt & built, natural & tourists & theory of reasoned action \\
\hline Trivedi, 2017 & [134] & Thailand & (destinations) & tourists & (unclear) \\
\hline $\begin{array}{l}\text { Buonincontri, Marasco, and } \\
\text { Ramkissoon, } 2017\end{array}$ & [135] & Italy & sites & visitors & theory of reasoned action \\
\hline $\begin{array}{l}\text { Brida, Dalle Nogare, } \\
\text { and Scuderi, } 2016\end{array}$ & [136] & Italy & (museums) & Tourists & rational addiction theory \\
\hline Farr et al., 2016 & [94] & Australia & natural (WHS) & tourists & WTP; equity theory \\
\hline Getzner, Färber, and Yamu, 2016 & [137] & Austria & natural & tourists & Economic valuation method \\
\hline $\begin{array}{l}\text { Lee, Phau, Hughes, Li, } \\
\text { and Quintal, } 2016\end{array}$ & {$[138]$} & Australia & urban & tourists & $\begin{array}{l}\text { consumer-based theory of } \\
\text { authenticity }\end{array}$ \\
\hline Martin et al., 2016 & [89] & Spain & urban (WHS) & tourists & Visitor experienced quality \\
\hline Brida, Meleddu, et al., 2016 & [97] & Italy & (museums) & visitors & behaviour segmentation \\
\hline
\end{tabular}


Table 2. Cont.

\begin{tabular}{|c|c|c|c|c|c|}
\hline Author, Year & Ref. & Country & Heritage & Actors & Theoretical Framework \\
\hline $\begin{array}{l}\text { Sabou, Nistoreanu, } \\
\text { and Maiorescu, } 2016\end{array}$ & [139] & Romania & urban & Tourists & Spatial analysis \\
\hline Khairi and Ismail, 2015 & [140] & Malaysia & urban (WHS) & tourists & Spatial analysis \\
\hline Mustafa, 2015 & [141] & Jordan & archaeological & tourists & $\begin{array}{l}\text { socialization theory; behavioural } \\
\text { intentions }\end{array}$ \\
\hline Ramkissoon, 2015 & [76] & Australia & (destination) & tourists & $\begin{array}{l}\text { attitude-behavior framework; } \\
\text { behavioral intention }\end{array}$ \\
\hline Huang, Weiler, and Assaker, 2015 & [142] & Australia & urban & tourists & consumer satisfaction theory; ТРВ \\
\hline Toha \& Ismail, 2015 & [143] & Malaysia & urban (WHS) & tourists & Tourist tracking; spatial analysis \\
\hline Di Pietro et al., 2015 & [98] & Italy & urban & visitors & behaviour segmentation \\
\hline Salvatierra and Walters, 2015 & [84] & Australia & natural & visitors & behavioural change \\
\hline Wolf et al., 2015 & [105] & Australia & natural & visitors & Outcomes-Focused Management \\
\hline Rani et al., 2014 & [109] & Malaysia & (destination) & tourists & Behavioral intention \\
\hline Romão et al., 2014 & [111] & Netherlands & natural (WHS) & tourists & behaviour segmentation \\
\hline $\begin{array}{l}\text { Ballantyne, Hughes, Ding, } \\
\text { and Liu, } 2014\end{array}$ & [144] & Australia & built & visitors & (unclear) \\
\hline Jones and Yamamoto, 2014 & [145] & Japan & natural (WHS) & visitors & WTP \\
\hline King and Halpenny, 2014 & [146] & Australia & (brand) & visitors & Branding theory \\
\hline $\begin{array}{l}\text { Bernadó, Bigorra, Pérez, Russo, } \\
\text { and Clave, } 2013\end{array}$ & [147] & Spain & urban (WHS) & tourists & Spatial analysis \\
\hline Li, Sia, and Zhu, 2013 & [148] & China & (destination) & tourists & Social exchange theory \\
\hline Wallace, 2013 & [149] & $\begin{array}{l}\text { United } \\
\text { Kingdom }\end{array}$ & $\begin{array}{l}\text { archaeological } \\
\text { (WHS) }\end{array}$ & visitors & Spatial analysis \\
\hline $\begin{array}{l}\text { Ramkissoon, Smith, } \\
\text { and Weiler, } 2013\end{array}$ & [150] & Australia & natural & visitors & Behavioural intentions \\
\hline Boukas, 2012 & [151] & Cyprus & archaeological & visitors & importance-satisfaction analysis \\
\hline Ramkissoon and Uysal, 2011 & [75] & Mauritius & sites & tourists & Behavioral intentions; TPB \\
\hline Yang, Hens, De Wulf, and Ou, 2011 & [152] & China & natural (WHS) & tourists & (unclear) \\
\hline Boley, Nickerson, and Bosak, 2011 & [153] & USA & (destination) & visitors & (unclear) \\
\hline Ramkissoon and Uysal, 2010 & [112] & Mauritius & sites & tourists & Behavioural intentions \\
\hline McNamara and Prideaux, 2010 & [154] & Australia & natural (WHS) & visitors & (unclear) \\
\hline Weiler and Ham, 2010 & [155] & Australia & sites & visitors & (unclear) \\
\hline Barton et al., 2009 & [106] & $\begin{array}{l}\text { United } \\
\text { Kingdom }\end{array}$ & natural & visitors & Rosenberg self-esteem scale \\
\hline McKercher et al., 2008 & [156] & China & natural & visitors & Neutralization theory \\
\hline Cooper, 2000 & [157] & Australia & natural (WHS) & visitors & (unclear) \\
\hline Fellenius, Williams, and Hood, 1999 & [158] & Canada & (destination) & tourists & behavior segmentation \\
\hline $\begin{array}{l}\text { Suryawardani, Wiranatha, } \\
\text { and Petr, } 2016\end{array}$ & [159] & Indonesia & (destination) & tourists & Expectancy theory \\
\hline $\begin{array}{l}\text { Hidalgo-Fernández, } \\
\text { Hernández-Rojas, Jimber del Río, } \\
\text { and Casas-Rosal, } 2019\end{array}$ & [160] & Spain & $\begin{array}{l}\text { archaeological } \\
\text { (WHS) }\end{array}$ & tourists & American customer satisfaction index \\
\hline
\end{tabular}

Literature focused on residents' behaviours, shown in Table 3, correspondents to almost one third $(27 \%)$ of the analysed publications. It often refers to urban heritage, for instance, measuring factors affecting residents' support for sustainable heritage tourism development (e.g., [81,161-163]). Centred on built heritage, Cai and $\mathrm{Lu}$ [164] determined aspects affecting residents' social integration in historic blocks, while Judson et al. [165] analyse how residents balance energy needs and heritage significance in renovation processes. A significant number of publications about residents $(13 \%)$ target intangible cultural heritage (ICH), such as the research of $\mathrm{Su}, \mathrm{Li}$, Wu and Yao [166] which develops a scale to measure inheritors' perception of ICH value, or the research of Yuan, Lun, He et al. [167] which explores community perspectives on traditional ecological knowledge. 
Table 3. Literature referring to residents and local communities.

\begin{tabular}{|c|c|c|c|c|c|}
\hline Author, Year & Ref. & Country & Heritage & Actors & Theoretical Framework \\
\hline Chong, 2020 & [161] & Malaysia & (resources) & community & (unclear) \\
\hline Su et al., 2020 & [166] & China & intangible & inheritors & value cognition \\
\hline Gannon et al., 2020 & [162] & Malaysia & urban & residents & $\begin{array}{l}\text { social exchange theory; theory of } \\
\text { substantive and formal rationality }\end{array}$ \\
\hline Megeirhi et al., 2020 & [81] & South Africa & urban (WHS) & residents & value-belief-norm \\
\hline $\begin{array}{l}\text { Qiu, Zheng, Xiang, } \\
\text { and Zhang, } 2020\end{array}$ & [168] & China & intangible & residents & $\begin{array}{l}\text { value-attitude-behaviour } \\
\text { hierarchy }\end{array}$ \\
\hline $\begin{array}{l}\text { Prados-Peña, } \\
\text { Gutiérrez-Carrillo, } \\
\text { and Barrio-García, } 2019\end{array}$ & [170] & Spain & built & community & branding \\
\hline Davoodi and Dağlı, 2019 & [171] & Turkey & urban & residents & (unclear) \\
\hline Gursoy, Zhang, and Chi, 2019 & [172] & China & urban (WHS) & residents & value orientation; identity theory \\
\hline Dragouni and Fouseki, 2018 & [93] & United Kingdom & (destinations) & community & WTP \\
\hline Cai and Lu, 2018 & [164] & China & built & residents & (unclear) \\
\hline Chen and Yang, 2018 & [175] & China & urban & residents & $\begin{array}{l}\text { Bourne's relocation } \\
\text { decision model }\end{array}$ \\
\hline $\begin{array}{l}\text { López, Virto, Manzano, } \\
\text { and Miranda, } 2018\end{array}$ & [176] & Spain & urban & residents & triple bottom line \\
\hline $\begin{array}{l}\text { Yasin, Abdullah, Ibrahim, } \\
\text { Khalid, and Wahab, } 2018\end{array}$ & [177] & Malaysia & urban (WHS) & residents & (unclear) \\
\hline Goldberg et al., 2018 & [178] & Australia & natural (WHS) & $\begin{array}{l}\text { residents, } \\
\text { tourists }\end{array}$ & TPB \\
\hline Domic and Boukas, 2017 & [179] & Cyprus & intangible & communities & $\begin{array}{l}\text { critical ethnography; } \\
\text { behaviour segmentation }\end{array}$ \\
\hline $\begin{array}{l}\text { Wang, Zhang, Han, } \\
\text { and Liang, } 2017\end{array}$ & [180] & China & Built, natural (WHS) & community & ground theory; role theory \\
\hline Goldberg et al., 2016 & [73] & Australia & Natural (WHS) & residents & (unclear) \\
\hline Lwoga, 2016 & [184] & Tanzania & built & residents & TPB \\
\hline May-Chiun and Songanc, 2014 & [185] & Malaysia & (destination) & communities & (unclear) \\
\hline Bosman and Whitfield, 2014 & [186] & South Africa & built & community & $\begin{array}{l}\text { vernacular theory; theory of } \\
\text { ecological perception }\end{array}$ \\
\hline $\begin{array}{l}\text { Judson et al., } 2014 \\
\text { Yuan et al., } 2014\end{array}$ & $\begin{array}{l}{[165]} \\
{[167]}\end{array}$ & $\begin{array}{l}\text { United Kingdom } \\
\text { China }\end{array}$ & $\begin{array}{l}\text { built } \\
\text { intangible }\end{array}$ & $\begin{array}{l}\text { homeowners } \\
\text { residents }\end{array}$ & $\begin{array}{l}\text { Social practice theory } \\
\text { (unclear) }\end{array}$ \\
\hline $\begin{array}{l}\text { Omar, Muhibudin, Yussof, } \\
\text { Sukiman, and Mohamed, } 2013\end{array}$ & [187] & Malaysia & Urban (WHS) & community & Stakeholders theory \\
\hline $\begin{array}{l}\text { Yunus, Karim, } \\
\text { and Samadi, } 2013\end{array}$ & [188] & Malaysia & natural & community & (unclear) \\
\hline Ma, Zhao, and Gong, 2013 & [189] & China & natural & residents & (unclear) \\
\hline $\begin{array}{l}\text { Ryan, Chaozhi, } \\
\text { and Zeng, } 2011\end{array}$ & [190] & China & Built (WHS) & residents & (unclear) \\
\hline Nicholas, Thapa, and Ko, 2009 & [191] & USA & Natural (WHS) & residents & Stakeholders theory \\
\hline $\begin{array}{l}\text { Senaratne, Abeygunawardena, } \\
\text { and Jayatilake, } 2003\end{array}$ & [192] & Sri Lanka & Natural (WHS) & residents & Household production theory \\
\hline
\end{tabular}

The publications referring to other stakeholders (from business owners to decision-makers) are presented in Table 4 . Only $2 \%$ of the studies approach behaviour in the perspective of the decision-makers. No studies were found about practitioners and designers involved in the conservation of built heritage. In this group, natural heritage is the most frequent type. For example, the research of Chi, Zhang and Liu [193] analysed managers of tourism companies in a natural heritage site, to study their corporate social responsibility behaviours (the integration of environmental and social concerns in business operations), while Esparon, Gyuris and Stoeckl [194] analysed the impact of eco-certification on consumers' choice of tourism operators. Several studies use students as the research population. While in some cases this choice reflects a convenience sampling, aimed at representing other actors, like potential visitors or the general community (e.g., [195]), in other cases this designation reflects the actual population, such as in the case of Rose, Rose and Merchant [196], that analyses the effect of 
heritage brands in students intentions to apply to a university, or the research of Forleo, Romagnoli and Palmieri [197] that recognises in students the potential to shape a system of values and beliefs for the future of sustainable development.

Table 4. Literature referring to other stakeholders.

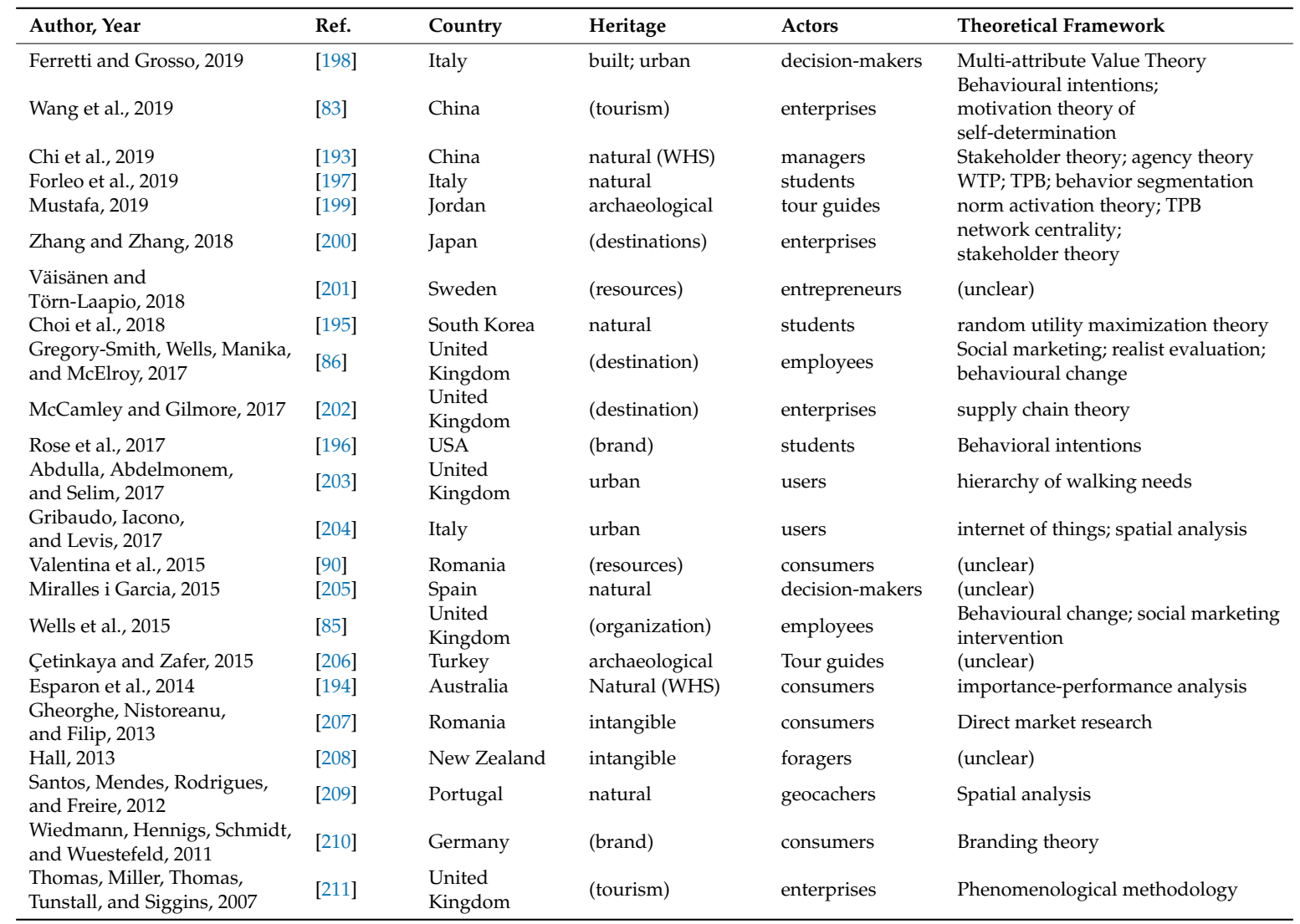

\subsubsection{Theoretical Frameworks and Research Methods}

Regarding the methodology, three types of information emerged: theoretical frameworks, data collection instruments, and data processing techniques. However, not always publications include a clear methodological framework, with the three types of information, with the theoretical framework missing in around $20 \%$ of the publications.

The diagram in Figure 2 presents the distribution of techniques according to the identified goals. Interviews are currently used in qualitative studies, aimed at eliciting respondents' values and attitudes (e.g., $[165,180,188,201])$. Visitor sensing or tracking is the predominant technique in studies about spatial behaviour, focused on understanding crowd movements in museums or urban spaces (e.g., $[114,139,140,147,149])$. Experimental interventions are a common method when addressing behavioural change (e.g., [84,85,87]), but were also found in the context of willingness-to-pay studies [137] and business intentions [212]. The most common method for data collection in the survey, allowing to cover most of the identified aims, was a quantitative approach. The results are then commonly analysed with factor analysis (CFA/EFA), to reduce the number of variables to a few constructs, followed by structural equation modelling (SEM), to establish relationships between latent constructs, according to a pre-established hypothesis (e.g., [78,79,81,109,112,123,162,170]). 


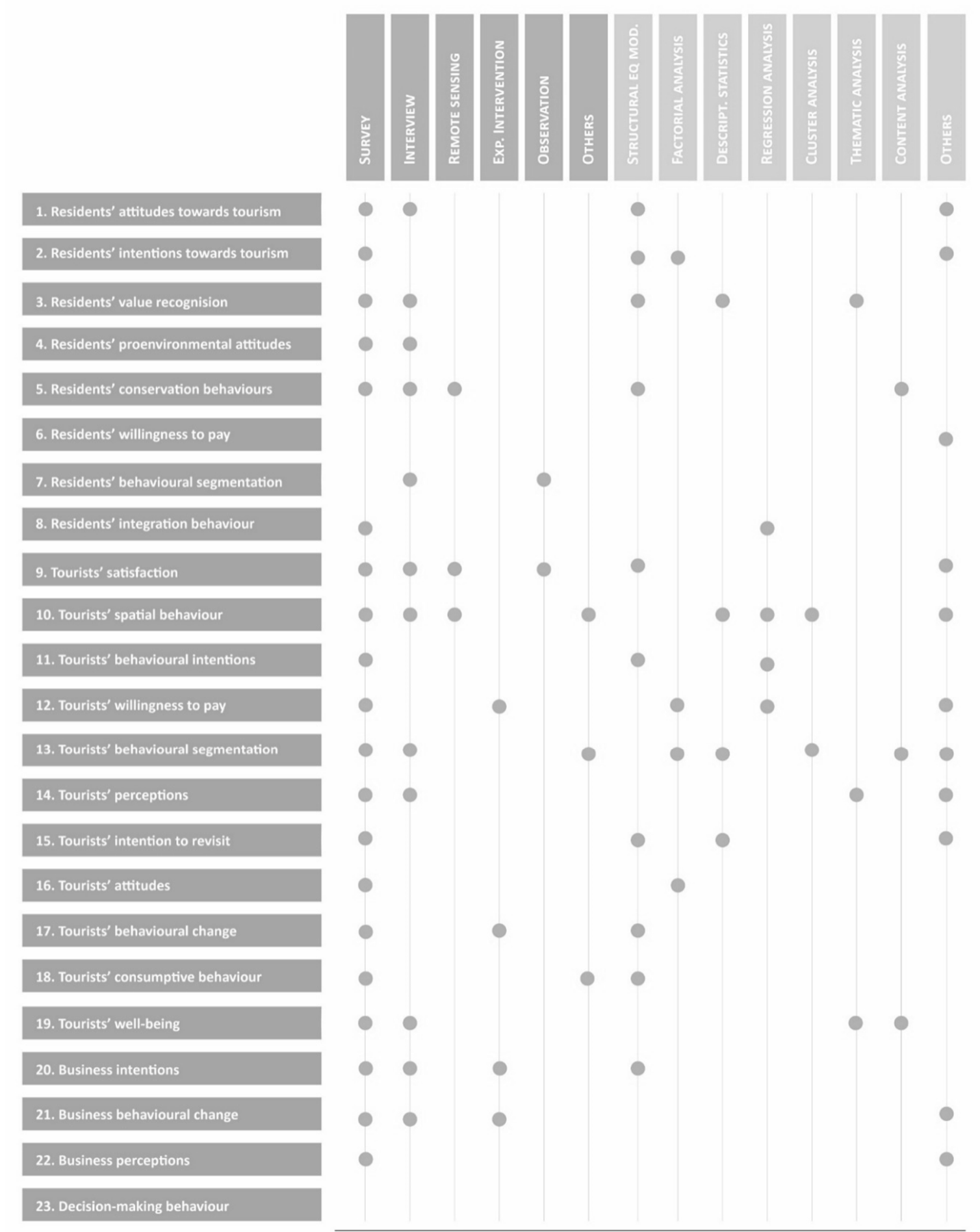

Figure 2. Distribution of data collection and data analysis techniques according to research aims.

The analysis allows for identifying a great diversity of theoretical approaches. Despite that, three trends emerge that confirm the identified aims: (1) theory of planned behaviour and theory of reasoned action, aimed at measuring intentions and predict behaviours; (2) behavioural segmentation theory, used in studies aiming at clustering individuals according to behavioural profiles; (3) willingness to pay, aiming at measure customer priorities and value judgements towards a given service or product. Together, these theoretical frameworks represent a quarter of the analysed publications. Even if only $11 \%$ of the analysed publications refer directly 
to Ajzen's theories of behavior [74,75,77,80,82,133,135,142,173,174,178,184,197,199], another $8 \%$ of the publications directly target behavioural intentions within a similar conceptual framework $[76,78,79,83,109,112,115,127,141,150,196]$. Together with the studies on behavioural change [84-87], and targeting decision-makers with a clear methodology [198], these records are further analysed in the next section.

\subsection{Behavioral Intentions and Behavioural Change for Sustainable Heritage}

To answer the research question, the next section presents an in-depth analysis of the publications based on the TRA and on the TPB, those focused on practitioners and decision-makers' behaviour, and the publications that present the results of interventions designed for behavioural change. Considering the overlapping between the three topics, a total of 30 publications were analysed. Most of the literature found $(68 \%)$ was published after 2017, and no results were found before 2010. Most of the results are from China and Australia, and together they represent half of the publications in the field $(47 \%)$. The summary of the findings is presented in Table 5 .

Table 5. Summary of main goals and methodologies found in the literature.

\begin{tabular}{|c|c|c|c|c|c|c|}
\hline Author, Year & Ref. & Country & Heritage & Constructs & Method & Population \\
\hline Piramanayagam et al., 2020 & [79] & India & archaeological & $\begin{array}{l}\text { destination image; visitor } \\
\text { experience; intention to revisit }\end{array}$ & $\begin{array}{l}\text { Questionnaire; } \\
\text { CFA; SEM }\end{array}$ & 384 tourists \\
\hline Yuan et al., 2019 & [82] & China & urban & $\begin{array}{l}\text { involvement, perceived } \\
\text { impacts, place attachment, } \\
\text { intention to support tourism }\end{array}$ & $\begin{array}{l}\text { Questionnaire; } \\
\text { SEM }\end{array}$ & 336 residents \\
\hline Wang et al., 2019 & [83] & China & (tourism) & $\begin{array}{l}\text { lifestyle-oriented motivation, } \\
\text { corporate social responsibility, } \\
\text { operational intention }\end{array}$ & $\begin{array}{l}\text { Questionnaire; } \\
\text { SEM }\end{array}$ & $\begin{array}{l}154 \text { guesthouse } \\
\text { owners }\end{array}$ \\
\hline Nian et al., 2019 & [74] & China & natural & $\begin{array}{l}\text { perception of OUV, service } \\
\text { quality, place attachment, } \\
\text { conservation intention }\end{array}$ & $\begin{array}{l}\text { Questionnaire; } \\
\text { SEM }\end{array}$ & 563 tourists \\
\hline Zhang et al., 2019 & [173] & China & built & $\begin{array}{l}\text { attitudes, subjective norms, } \\
\text { perceived control, } \\
\text { self-regulation, social capital, } \\
\text { intention and behaviour } \\
\text { towards conflict }\end{array}$ & $\begin{array}{l}\text { Interview; } \\
\text { questionnaire; } \\
\text { SEM }\end{array}$ & 250 residents \\
\hline Zhang and Wang, 2019 & [80] & China & urban & $\begin{array}{l}\text { attitudes, motivation, } \\
\text { space emotion, subjective } \\
\text { norms, perceived control, } \\
\text { travel intention }\end{array}$ & $\begin{array}{l}\text { Questionnaire; } \\
\text { SEM }\end{array}$ & 650 tourists \\
\hline Bergel and Brock, 2019 & [77] & Germany & natural & $\begin{array}{l}\text { affective attitude, influence } \\
\text { behaviour, destination loyalty } \\
\text { intention, perception of } \\
\text { entrance fees }\end{array}$ & $\begin{array}{l}\text { Questionnaire; } \\
\text { SEM }\end{array}$ & 802 visitors \\
\hline Mustafa, 2019 & [199] & Jordan & archaeological & $\begin{array}{l}\text { value orientation, social norms, } \\
\text { commitment to conservation }\end{array}$ & $\begin{array}{l}\text { Questionnaire; } \\
\text { SEM }\end{array}$ & 96 tour guides \\
\hline Zhang et al., 2019 & [174] & China & natural & $\begin{array}{l}\text { livelihood strategies, } \\
\text { perception of changes, } \\
\text { pro-environmental behaviours }\end{array}$ & $\begin{array}{l}\text { Interviews: } \\
\text { questionnaire; } \\
\text { multiple } \\
\text { regression }\end{array}$ & 314 residents \\
\hline Ferretti and Grosso, 2019 & [198] & Italy & built & $\begin{array}{l}\text { power-interest matrix; } \\
\text { preferences; values; trade-offs }\end{array}$ & $\begin{array}{l}\text { Stakeholders } \\
\text { analysis }\end{array}$ & Decision-makers \\
\hline Forleo et al., 2019 & [197] & Italy & natural & $\begin{array}{l}\text { use and non-use values; } \\
\text { willingness-to-pay; } \\
\text { pro-environmental behaviours }\end{array}$ & $\begin{array}{l}\text { Questionnaire; } \\
\text { hierarchical } \\
\text { cluster analysis }\end{array}$ & 542 students \\
\hline Chow et al., 2019 & [115] & China & natural & $\begin{array}{l}\text { place attachment; satisfaction; } \\
\text { pro-environmental intentions }\end{array}$ & $\begin{array}{l}\text { Questionnaire; } \\
\text { regression }\end{array}$ & 402 tourists \\
\hline Mehmood et al., 2018 & [127] & China & natural & $\begin{array}{l}\text { word-of-mouth; user generated } \\
\text { content; heritage image; } \\
\text { attitudes; travel intention }\end{array}$ & $\begin{array}{l}\text { Questionnaire; } \\
\text { SEM }\end{array}$ & 280 tourists \\
\hline Goldberg et al., 2018 & [178] & Australia & natural & $\begin{array}{l}\text { attitudes; perceived barriers; } \\
\text { pro-environmental behaviours }\end{array}$ & $\begin{array}{l}\text { Questionnaire; } \\
\text { Variance inflation } \\
\text { factors }\end{array}$ & $\begin{array}{l}3181 \text { residents; } \\
2621 \text { tourists }\end{array}$ \\
\hline Kim et al., 2018 & [78] & USA & natural & $\begin{array}{l}\text { perceived sustainability, } \\
\text { pro-environmental behaviour; } \\
\text { revisit intention; } \\
\text { word-of-mouth }\end{array}$ & $\begin{array}{l}\text { Questionnaire; } \\
\text { CFA; SEM }\end{array}$ & 300 tourists \\
\hline
\end{tabular}


Table 5. Cont.

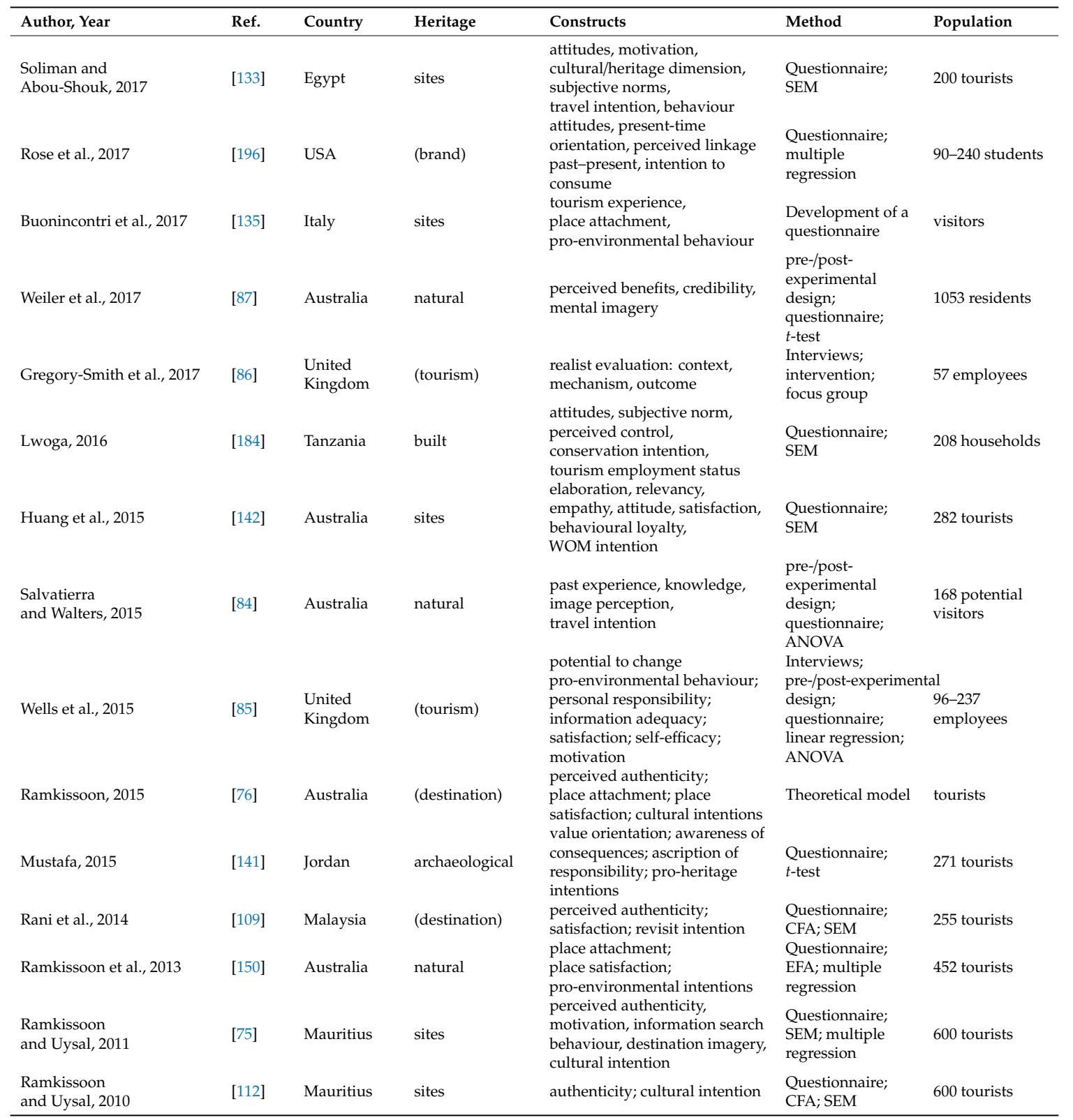

\subsubsection{Sustainable Heritage Conservation}

Sustainability is the journal with more publications on the topic (19\%), followed by the J. Travel Res. (14\%). Despite mostly being published under the topic of "social sciences" (57\%), the majority of studies were published in journals of the tourism and hospitality field (62\%), confirming the predominance of studies focusing on tourist behaviour and in the notion of heritage as a destination. In more than half of the publications (65\%), the term "sustainability" is used in the context of sustainable tourism development and heritage destinations [74,77,80,83,133,135,173,174,199].

Sustainable heritage is not a clear concept, and, even if often mentioned, is rarely defined. Despite that, two main approaches emerge in the literature: one targeting environmental protection, and another one more focused on the social dimension, targeting community participation. Lwoga [184] and Yuan et al. [82] state that the engagement of local communities is essential to achieve a sustainable heritage management. While Lwoga [184] studies residents' intention to conserve built heritage, Yuan et al. [82] focus on residents' intentions to support tourist development. Additionally, 
Zhang et al. [173] contribute to improve inclusive decision practices, by analysing residents' behaviours towards conflict resolution.

The environmental dimension of sustainability is addressed in $40 \%$ of the publications (e.g., [74,77,84,85,133]). Chow et al. [115] analyse tourists' environmentally responsible behaviours in the context of natural heritage, aiming at contributing to reduce tourism negative environmental impacts. Moreover, Forleo et al. [197] and Goldberg et al. [178] focus on the protection of areas with environmental value and on their long-term preservation for future generations. The research of Buonicontri et al. [135] develops a scale to measure factors affecting the sustainable behaviour of heritage visitors, developing a set of indicators to assess pro-heritage behaviours (limiting visits to heritage sites, donations and willingness to pay for preservation, engaging in voluntary work, etc.) Additionally, the study of Wang et al. [83] considers environmental and heritage protection as two essential vectors of corporative socially responsible practices, in the context of sustainable tourism.

In both approaches to sustainability (social and environmental), the analysed literature focused on anthropogenic pressure, touristic pressure, and on the overexploitation of resources. Nian et al. [74] and Kim et al. refer to the need to avoid the overexploitation of tourism facilities and the uncontrolled touristic capacity, in order to protect the ecological environment from intensive land use and deterioration of biodiversity. For Zhang and Wang [80], sustainable tourism must avoid the negative impacts of mass tourism, while maximizing tourism's benefits, by creating employment and increasing income of local communities. Furthermore, Buonicontri et al. [135] refer to sustainable tourism as a balance operation, between visitation, authenticity, and conservation.

\subsubsection{Built Heritage}

More than one third (38\%) of the publications analysed refer to natural heritage, and $15 \%$ refer to heritage sites-including, but not specifying, museums, monuments, archaeological, historical, and natural sites. Only in $15 \%$ of the cases, studies focus on built heritage.

In the context of built heritage, some authors, i.e., Lwoga [184] and Zhang et al. [173], use the TPB to analyse the residents' behavioural intentions in heritage buildings. Lwoga [183] elicits the tourism employment status as a moderator of conservation intentions, by imposing more perceived social pressure over respondents. It shows that raising awareness for heritage conservation has the potential to elevate positive attitudes and, at the same time, trigger social pressure to conserve, acting on two socio-psychological factors affecting residents' engagement. Zhang et al. [173] identified common themes of conflict for residents, related to the protection of the traditional building (comfort and quality of life, allocation of maintenance duties, or protection regulations, for instance) and the sharing of tourism benefits (profit distribution or property rights, etc.) Like the study of Lwoga [184], it shows that favourable attitudes are the most important variable to determine residents' intention to engage in conflict resolution within cultural heritage management.

\subsubsection{Decision-Makers}

The analysed studies focusing on tourists' behaviour represent $60 \%$ of the sample, followed by residents' behaviour (22\%). No studies were found analysing the behaviours of practitioners involved in heritage conservation processes. Only the study of Ferretti and Grosso [198] targets directly the behaviour of decision-makers in the conservation of built heritage. It uses a stakeholder analysis methodology to develop a tool for decision-making that considers the weight of each stakeholder, developing a power-interest matrix and eliciting values and possible trade-offs. This research is not focused on analysing behavioural intentions or the dissonance between intentions and implementation and does not use the theoretical framework under analysis in the present research.

\subsubsection{Research Methods}

On average, the studies have a sample of 584 respondents, which allows for statistically significant analysis using structural equation modelling, with a recommended minimum of 200 
respondents [82,112]. The studies of Wang et al. [83] and Mustafa [199], however, use the structural equation modelling despite not meeting this criterion, considering the provided samples as representative of the studied population. Multiple regression $[75,150,174,196], t$-tests $[87,141]$, and one-way variance analysis-ANOVA $[84,85]$ are also used to establish relations between the questionnaire variables and to confirm the hypothesis.

All the questionnaires use Likert scales to assess the level of agreement/disagreement of respondents with given statements. Some studies include a preparatory step with interviews $[85,86,173,174]$ or preliminary surveys $[75,196]$ to elicit modal accessible beliefs (conscious beliefs common to the majority of the population). All the studies that target behavioural change suggest two-step methodologies, with pre-/post-experimental design, surveying or interviewing the population before and after applying the intervention [84-87].

\subsubsection{Psychological Constructs}

The most common aim in the literature is to elicit other constructs that affect respondents' intentions and behaviours, from perceptions to motivations. Intention is the most common psychological construct included in the analysis. This construct targets mainly 3 groups of behaviours: (1) pro-environmental or environmentally responsible behaviours (e.g., [78,85,115,135,178,197]); (2) pro-heritage or heritage protection behaviours (e.g., [74,141,184,199]); (3) travel behaviours, including loyalty and intention to revisit (e.g., $[77,79,127,133,142])$. The third group, on travel behaviours, represents around $50 \%$ of the analysed publications.

On average, each questionnaire relates four psychological constructs. Respondents' perceptions are a recurrent factor, approached in $36 \%$ of the studies, in the context of perceived authenticity and outstanding value of heritage [74,75,133], perceived tourism impacts, and perceived benefits of visitation [82,87], for instance. Motivations (the reasons that pull people to perform certain behaviours, such as lifestyle, economic, social integration, etc. [75,80,83,133]), satisfaction (e.g.: [76,109,115,142,150]), and place attachment (e.g., $[74,76,82,115,135]$ are also common constructs in the literature.

\subsubsection{Interventions for Behavioural Change}

The study conducted by Salvatierra and Walters [84] designed an intervention to assess the impact of media on travellers' image perception and intentions about a destination. Results show that the public is increasingly aware of environmental sustainability practices, and of those that can affect image perception and intention to visit. This study also outlines previous knowledge and educational background of moderators of this relationship. Furthermore, Weiler et al. [87] used a pre-post experimental design methodology to analyse the effect of communication interventions to shift public perceptions. The results show an increased perception of the benefits of natural parks after exposed to persuasive communication in the short-term. The research of Wells et al. [85] applies a pre-/post-experimental intervention to measure changes in the perceived satisfaction of employees when introduced to a "sustainability toolkit" that allows them to determine their sustainability plan and priorities. The findings support that being exposed to information provided knowledge to employees and increased their awareness on environmental issues. The proxy measure of actual behaviour showed a reduction in energy consumption during the period of the intervention. The evaluation of the experiment [86] elaborates that realistic interventions are partial and context-tailored but confirms that educational mechanisms may tackle knowledge and belief gaps. It states, however, that the effects of social interventions tend to decline as time passes, and suggests monitoring, empowerment, and support as tools to guarantee long-lasting effects.

\subsubsection{Practical Implications}

At a theoretical level, the analysed publications contribute to establishing internal attitudes and motivations as a key factor for sustainable conservation behaviours [80,82,83,133,173]. Despite not focusing on instigating practitioners' behavioural intentions and behavioural change for the sustainable 
conservation of the built heritage, the publications analysed provided several theoretical managerial contributions to the heritage field.

The research of Bergel and Brock [77] concluded that engagement contributes to more positive attitudes for tourists, and that the willingness to pay for more sustainable services is affected by affective components, resulting from feelings and emotional ties to destinations. Furthermore, Zhang and Wang [80] point out the emotional connection with the destination as one of the main factors determining tourists' intentions to revisit. Both studies suggest that marketing strategies need to build affective connections to engage visitors and attract customers.

Place attachment, i.e., the affective relationships between individuals and specific places, also plays a role in residents' intentions and behaviours. Yuan et al. [82] demonstrate that both cognitive and affective attitudes are determinant for residents' support of tourism development. This proves the need for authorities "to enhance the relationship between residents and the city" [82], supporting the sense of identity through long-term continuity of residents, and respecting communities' emotional bonds with tangible and intangible attributes.

The research of Goldberg et al. [178] shows that the sense of identity is also important for increasing the perceived individual responsibility, affecting the decision to take actions to protect the environment. As such, facilitating people's connections to nature may have practical implications on conservation outcomes. The research of Nian et al. [74] found a positive intention to protect heritage when visitors recognise and emotionally connect to the attributes identified as outstanding universal value (OUV) in the World Heritage Site (WHS) listing, evidencing the need for participatory processes that recognise community values in the WHS evaluations. Ramkissoon and Uysal [75] proved that authenticity may have different meanings and connotations according to site and experience and that it mediates tourists' choices.

Several authors point out the benefits of behavioural approaches to increase cooperation between stakeholders and to inform policies and strategies for sustainability $[80,135,184]$. According to Forleo et al. [197], the contribution of these approaches to identify the most valuable attributes for communities, can support managers to find synergies and reduce trade-offs. Furthermore, Zhang et al. [173] point out that knowledge of the particular behaviours associated with different groups of stakeholders contributes to better understand their roles in decision-making processes. This knowledge is fundamental to assist managers to plan more effectively for the maximization of the conservation response $[112,178]$, since understanding the audience ensures that the information is conveyed and meets the desired goals [178].

The literature also suggests the meaningful role of education, and the potential of persuasive communication to raise levels of knowledge and awareness, inspiring positive attitudes and behavioural change $[84-87,184,197]$. The research of Gregory-Smith et al. [86] shows that educational mechanisms can tackle knowledge and belief gaps in organizational environments. Likewise, Forleo et al. [197] suggest that education can be determinant to increase awareness, attitudes, and preservation behaviours in natural areas. In the context of archaeological heritage, Mustafa [141] recommends education, and in particular behavioural education, to enhance responsible behaviours. Further, Lwoga [184] suggests that communicating conservation benefits and empowering communities with knowledge and skills, has the potential to elevate positive attitudes and thus increase conservation behaviours.

\section{Discussion}

The literature review corroborates claims for the existence of a performance gap between planning and implementation $[177,205,213]$. According to Shi et al. [213], because a building is a complex system, it is not possible to ensure performance in every aspect exactly as intended at the design stage. At the territorial planning level, Miralles i Garcia [205] points out profitability and land policies as some of the factors in the failure of the implementation of any plan. Further, other studies [214-216] have pointed out different challenges in built heritage conservation, such as insufficient knowledge and skills, that are consistent with low perceived behavioural control. The awareness of this gap between 
intended and actual performance contributed, in the building and construction field, to the continuous development of modelling and simulation techniques to improve the accuracy of predictions. In this context, the concept of behaviour is used to focus on one particular actor: the building. In almost one-third of the results, behaviour is used as a synonym of performance and used to refer to buildings' structural characteristics or hygrothermal and thermal performance. Despite the variety of stakeholders involved in the complex processes of building conservation, no significant number of studies were found analysing their behaviours leading to the implementation (or not) of planned intentions. Occupants' behaviour is an exception in the building and construction sector and it is often referred to by its impact on the energy performance of buildings [217-222]. However, the literature review points occupant behaviour as a factor-one of several things that influence the results, but not as the core of the detailed analysis.

It is in the tourism and hospitality field that most results relating socio-psychological constructs of behaviour and heritage sustainability can be found, predominantly in the perspective of residents and tourists. While no studies were found concerning practitioners and designers engaged in conservation processes, the research with residents and tourists evidences the potential of behavioural sciences to contribute to a better understanding of factors affecting intentions towards heritage conservation. In 1974, Ajzen theorised that knowledge about attitudes improves the prediction of behaviours, but intervening factors may attenuate this relation [25]. This is confirmed by the studies analysed in the literature review that evidence attitudes as a fundamental factor in the formation of intention $[80,82,83,133,173]$, but also the role of norms and perceived control in this relation [184,199]. Most of the analysed publications aim at identifying and assessing factors affecting behaviours, such as place attachment, authenticity, perceptions, or motivations. The behaviours analysed are related to destination choice but also with pro-environmental and pro-heritage behaviours. The affective components of attitude-resulting from feelings and emotions, as opposed to cognitive attitudes based on knowledge and information-seem to play an important role in behaviours related to heritage conservation $[76,77,80,112,178]$.

No studies were found addressing the cognitive dissonance between intentions and behaviours. This may explain the small percentage of studies using the TRA and the TPB as theoretical frameworks, the most common frameworks to tackle this issue in other fields [24,25,27,30]. In common with the previously identified literature addressing the inconsistency between intention and behaviour (Section 1.1), the publications presenting interventions for behavioural change used two-wave methodologies, with pre-/post-experimental designs. This approach allows for accurate measurement of two phenomena: inconsistency of intentions and behaviours [33,222]; and rate of implementation after the intervention $[39,84,85,87]$. While Sheeran and Webb [27] recommend implementation intentions as one of the main tools to increase intention realization, no studies were found in the heritage field about this topic. On the other hand, the role of training and education is found repeatedly in the literature on the heritage field: Gregory-Smith et al. [86] suggest that educational mechanisms may tackle knowledge and belief gaps; Weiler et al. [87] demonstrate that being exposed to information, through persuasive communication, increases the perception of the benefits of natural parks; Salvatierra and Walters [84] found knowledge and educational background as moderators of intention and image perception; Lwoga [184] suggests that empowering residents with knowledge about conservation benefits may increase positive attitudes and social pressure. This knowledge is essential for planners and decision-makers to find effective managerial solutions for sustainable conservation.

\section{Future Research}

In this review, evidence suggests the need for a new approach in the study of practitioners' behaviours towards a sustainable conservation of the built heritage. Sustainable heritage is a multidimensional and subjective concept that varies across contexts. However, by looking at it from a behavioural perspective, it is evident that it has been approached more often in the scope of 
residents' and tourists' environmental behaviours. A gap was found in the study of the interrelation between intention and behaviour of practitioners involved in conservation processes.

From the results of this review, a future line of research has been developed, proposing to identify which psychological constructs (attitude, norm, perception of control) is more determinant to convert designers' intentions into actual conservation practices. By understanding these factors, it should be possible to shed light on the reasons why sustainable conservation approaches are not more widely implemented in built heritage.

Drawing from Ajzen's TPB [22,23], this approach has the goal of going beyond good intentions and proposes a behavioural intervention to tackle the issues found and contribute for the implementation of sustainable conservation behaviours. The diagram in Figure 3 shows the sequential steps of the purposed pre-/post-experimental methodology [26]: (1) identification of modal accessible beliefs; (2) measure of the existing intention-behaviour inconsistency; (3) design of the intervention according to the most influent psychological constructs; (4) measurement of the intention-behaviour inconsistency after the intervention.

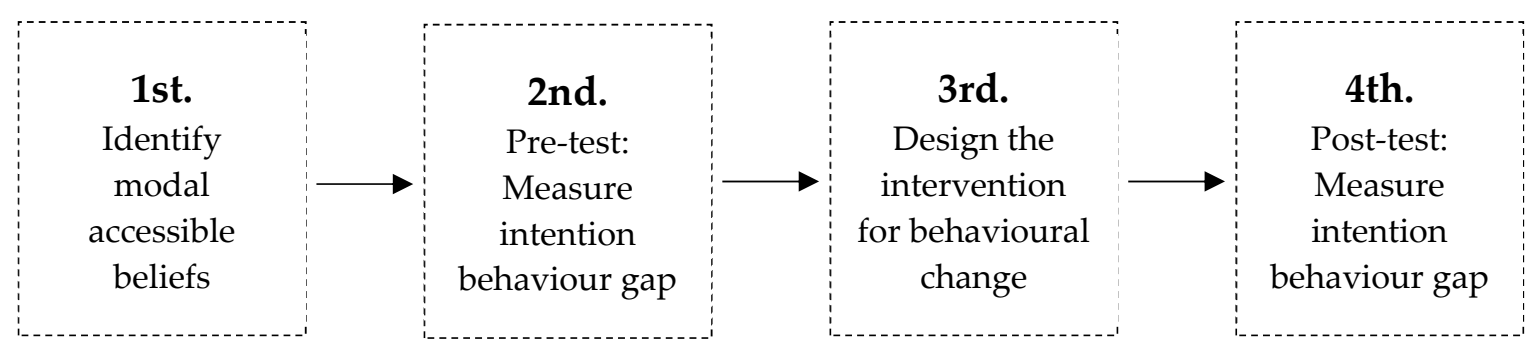

Figure 3. Methodological steps to test an intervention to reduce the intention-behaviour gap.

The contribution of such an approach is to facilitate the identification of factors affecting the implementation of good practices for sustainable conservation, so that future research on policies and design tools can be directed towards the fundamental cognitions that hinder implementation. Decision-making includes conscious and unconscious processes. The effective change towards a more sustainable conservation of the built heritage depends on the unveiling of the underlying psychological processes.

One of the limitations of this research is that only one bibliographic database was used, which may have suppressed some relevant results. Further research can expand this study with other bibliographical search engines.

\section{Conclusions}

The literature review proved that a behavioural perspective on sustainable heritage is a very recent topic, even if the theoretical framework has been applied in other fields for decades. The results show that, in the construction sector, behaviour is mostly understood as performance, focusing on the building itself; occupants' behaviour is mentioned as a factor that affects performance, but no significant studies were found about a deeper analysis of the socio-psychological factors affecting occupant behaviour in heritage buildings. This socio-psychological perspective has been mostly introduced in the heritage field by the domain of tourism and hospitality management.

The main goal of this research was to understand the contributions of the TPB to increase the implementation of good practices on sustainable conservation. No studies were found using the TPB or the TRA in the scope of practitioners' behavioural change in the built heritage field. The existing literature does not allow to identify the main factors undermining the implementation of sustainable conservation practices in the built heritage. However, the research addressing other stakeholders involved in heritage management processes-such as tourists and residents-proves the potential of the theoretical framework for a better understanding of behaviours of the different stakeholders and to find managerial solutions for sustainable transitions This literature review demonstrates the novelty of 
utilizing behavioral approaches in sustainable heritage conservation. Furthermore, this review also allows for a clearer understanding of the more common trends adopted by pioneering researchers in the field, encouraging its development. Using the TPB as a theoretical framework to analyse practitioners' intentions and behaviours is a unique and innovative line of research that may clarify the reasons of the lack of implementation of sustainable practices and open the path for effective behavioural change.

Author Contributions: All authors contributed to the conception and design of the research work. J.G. collected the data, performed the analysis, and draft the article. R.M., J.D.S., and A.P.R. revised the manuscript critically for important intellectual content and approved the version of the manuscript to be published. All authors have read and agreed to the published version of the manuscript.

Funding: This research was funded by the Portuguese Foundation for Science and Technology (FCT) in the scope of the Doctoral Program Eco-Construction and Rehabilitation (EcoCoRe), to the PhD scholarship with the reference $\mathrm{PD} / \mathrm{BD} / 127853 / 2016$.

Acknowledgments: The authors would like to acknowledge the support granted by the Portuguese Foundation for Science and Technology (FCT), in the scope of the Doctoral Program Eco-Construction and Rehabilitation (EcoCoRe), to the PhD scholarship with the reference PD/BD/127853/2016, and the support of ISISE, from the UMinho, CERIS, from IST-UL, and of the Heritage \& Architecture section, from AE-T-BK at TU Delft.

Conflicts of Interest: The authors declare no conflict of interest.

\section{References}

1. UN Transforming Our World: The 2030 Agenda for Sustainable Development; United Nations: New York, NY, USA, 2015.

2. Gonçalves, J.; Mateus, R.; Silvestre, J.D.; Roders, A.P. Contributions to a Revised Definition of Sustainable Conservation. In Proceedings of the Conference Heritage and the Sustainable Development Goals, Delft, The Netherlands, 26-28 November 2019.

3. UNESCO. Recommendation on the Historic Urban Landscape; UNESCO: Paris, France, 2011.

4. Zamperini, E.; Cinieri, V. Lifecycle Oriented Approach for Sustainable Preservation of Historical Built Heritage. In Proceedings of the Built Heritage 2013: Monitoring Conservation and Management, Milano, Italy, 18-20 November 2013; Politecnico di Milano: Milano, Italy, 2013; pp. 465-474.

5. ICOMOS. The Wise Use of Heritage: Abstracts from the World Congress of the Conservation of Cultural Heritage during ICOMOS 12th General Assembly; ICOMOS: Mexico City, Mexico, 1999.

6. ICOMOS. The Paris Declaration on Heritage as a Driver of Development; ICOMOS: Paris, France, 2011; pp. 1-6.

7. UNESCO. The Hangzhou Declaration: Placing Culture at the Heart of Sustainable Development Policies; UNESCO: Hangzhou, China, 2013.

8. ICOMOS. The Valletta Principles for the Safeguarding and Management of Historic Cities, Towns and Urban Areas; 9781509033294; ICOMOS: La Valletta, Malta, 2011; pp. 1-18.

9. Fernandes, J.; Mateus, R.; Gervásio, H.; Silva, S.M.; Bragança, L. Passive strategies used in Southern Portugal vernacular rammed earth buildings and their influence in thermal performance. Renew. Energy 2019, 142, 345-363. [CrossRef]

10. Gonçalves, J.; Mateus, R.; Ferreira, T. Continuing Tradition: Farms in the northeast region of Portugal. In Vernacular Architecture: Towards a Sustainable Future; CRC Press: Boca Raton, FL, USA, 2014; pp. $363-368$.

11. Posani, M.; Veiga, M.D.R.; de Freitas, V.P. Towards resilience and sustainability for historic buildings: A review of envelope retrofit possibilities and a discussion on hygric compatibility of thermal insulations. Int. J. Archit. Herit. 2019, 13, 1-17. [CrossRef]

12. Pacheco-Torgal, F; Jalali, S. Earth construction: Lessons from the past for future eco-efficient construction. Constr. Build. Mater. 2012, 29, 512-519. [CrossRef]

13. Mendes, N.; Lourenço, P.B. Seismic assessment of masonry “Gaioleiro" buildings in Lisbon, Portugal. J. Earthq. Eng. 2009, 14, 80-101. [CrossRef]

14. Ortega, J.; Vasconcelos, G.; Rodrigues, H.; Correia, M.; Lourenço, P.B. Traditional earthquake resistant techniques for vernacular architecture and local seismic cultures: A literature review. J. Cult. Herit. 2017, 27, 181-196. [CrossRef]

15. Havinga, L.; Colenbrander, B.; Schellen, H. Heritage significance and the identification of attributes to preserve in a sustainable refurbishment. J. Cult. Herit. 2019, 43, 282-293. [CrossRef] 
16. Ornelas, C.; Miranda Guedes, J.; Sousa, F.; Breda-Vázquez, I. Supporting Residential Built Heritage Rehabilitation through an Integrated Assessment. Int. J. Archit. Herit. 2020, 14, 1-14. [CrossRef]

17. Pereira-Roders, A.R.; Post, J.M.; Erkelens, P.A. Re-Architecture: Reality or Utopia? In-House Publishing: Rotterdam, The Netherlands, 2008; pp. 2619-2626.

18. Appleton, J.A.S. Reabilitação de Edifícios Antigos: Patologias e Tecnologias de Intervenção; Edições Orion: Lisboa, Portugal, 2003.

19. Veldpaus, L.; Roders, A.R.P.; Colenbrander, B.J.F.; Veldpaus, L.; Roders, A.R.P.; Colenbrander, B.J.F. Urban Heritage: Putting the Past into the Future Urban Heritage: Putting the Past into the Future. Hist. Environ. Policy Pract. 2016, 7505, 2-18.

20. Vandesande, A. Preventive Conservation Strategy for Built Heritage Aimed at Sustainable Management and Local Development. Ph.D. Thesis, KU Leuven, Leuven, Belgium, 2017.

21. Albert, M.-T.; Bandarin, F.; Roders, A.P. Going Beyond: Perceptions of Sustainability in Heritage Studies No. 2; Springer: Berlin/Heidelberg, Germany, 2017.

22. Ajzen, I. From intentions to actions: A theory of planned behavior. In Action Control; Springer: Berlin/Heidelberg, Germany, 1985; pp. 11-39.

23. Ajzen, I. The theory of planned behaviour. Organ. Behav. Hum. Decis. Process. 1991, 50, 179-211. [CrossRef]

24. Ajzen, I.; Czasch, C.; Flood, M.G. From intentions to behavior: Implementation intention, commitment, and conscientiousness. J. Appl. Soc. Psychol. 2009, 39, 1356-1372. [CrossRef]

25. Ajzen, I.; Fisbbein, M. Factors Influencing Intentions and the Intention-Behavior Relation. Human Relations 1974, 27, 1-15. [CrossRef]

26. Ajzen, I. Behavioral Interventions Based on the Theory of Planned Behavior. Res. Policy 2002, 2011, 1-6.

27. Sheeran, P.; Webb, T.L. The Intention-Behavior Gap. Soc. Personal. Psychol. Compass 2016, 10, 503-518. [CrossRef]

28. Ajzen, I.; Fishbein, M. The preditction of behavior from attitudinal and normative variables. J. Exp. Soc. Psychol. 1970, 6, 466-487. [CrossRef]

29. Triandis, H.C. Values, attitudes, and interpersonal behavior. In Nebraska Symposium on Motivation; Page, H.H.M., Ed.; University of Nebraska Press: Lincoln, NE, USA, 1980; Volume 27, pp. 195-259.

30. Sheeran, P. Intention-Behavior Relations: A Conceptual and Empirical Review European Review of Social Psychology. Eur. Rev. Soc. Psychol. 2002, 12, 37-41. [CrossRef]

31. Shirokova, G.; Osiyevskyy, O.; Bogatyreva, K. Exploring the intention-behavior link in student entrepreneurship: Moderating effects of individual and environmental characteristics. Eur. Manag. J. 2016, 34, 386-399. [CrossRef]

32. Pieters, R.; Zeelenberg, M. On bad decisions and deciding badly: When intention-behavior inconsistency is regrettable. Organ. Behav. Hum. Decis. Process. 2005, 97, 18-30. [CrossRef]

33. van Hooft, E.A.J.; Born, M.P.; Taris, T.W.; van der Flier, H.; Blonk, R.W.B. Bridging the gap between intentions and behavior: Implementation intentions, action control, and procrastination. J. Vocat. Behav. 2005, 66, 238-256. [CrossRef]

34. Ajzen, I.; Fishbein, M. Predicting and Changing Behavior the Reasoned Action Approach; Taylor \& Francis: Abingdon, UK, 2010.

35. Budden, J.S.; Sagarin, B.J. Implementation Intentions, Occupational Stress, and the Exercise Intention-Behavior Relationship. J. Occup. Health Psychol. 2007, 12, 391-401. [CrossRef]

36. Chatzisarantis, N.L.D.; Hagger, M.S. Mindfulness and the intention- behavior relationship within the theory of planned behavior. Pers. Soc. Psychol. Bull. 2007, 33, 663-676. [CrossRef]

37. de Bruin, M.; Sheeran, P.; Kok, G.; Hiemstra, A.; Prins, J.M.; Hospers, H.J.; van Breukelen, G.J.P. Self-regulatory processes mediate the intention-behavior relation for adherence and exercise behaviors. Health Psychol. 2012, 31, 695-703. [CrossRef] [PubMed]

38. Ghany, M.G.; Strader, D.B.; Thomas, D.L.; Seeff, L.B. Diagnosis, management, and treatment of hepatitis C: An update. Hepatology 2009, 49, 133-1374. [CrossRef] [PubMed]

39. Fennis, B.M.; Adriaanse, M.A.; Stroebe, W.; Pol, B. Bridging the intention-behavior gap: Inducing implementation intentions through persuasive appeals. J. Consum. Psychol. 2011, 21, 302-311. [CrossRef]

40. Paul, J.; Modi, A.; Patel, J. Predicting green product consumption using theory of planned behavior and reasoned action. J. Retail. Consum. Serv. 2016, 29, 123-134. [CrossRef]

41. Wang, P.; Liu, Q.; Qi, Y. Factors influencing sustainable consumption behaviors: A survey of the rural residents in China. J. Clean. Prod. 2014, 63, 152-165. [CrossRef] 
42. Sang, P.; Yao, H.; Zhang, L.; Wang, S.; Wang, Y.; Liu, J. Influencing factors of consumers' willingness to purchase green housing: A survey from Shandong Province, China. Environ. Dev. Sustain. 2019, 22, 4267-4287. [CrossRef]

43. Du Toit, J.; Wagner, C.; Fletcher, L. Socio-spatial factors affecting household recycling in townhouses in Pretoria, South Africa. Sustainability 2017, 9, 2033. [CrossRef]

44. Ortiz, M.A.; Bluyssen, P.M. Proof-of-concept of a questionnaire to understand occupants' comfort and energy behaviours: First results on home occupant archetypes. Build. Environ. 2018, 134, 47-58. [CrossRef]

45. Boland, A.; Cherry, G.; Dickson, R. Doing a Systematic Review: A Student's Guide; Sage: London, UK, 2017.

46. Moher, D.; Liberati, A.; Tetzlaff, J.; Altman, D.G.; Group, P. Preferred reporting items for systematic reviews and meta-analyses: The PRISMA statement. PLoS Med. 2009, 6, e1000097. [CrossRef]

47. Ferreira, T.M.; Mendes, N.; Silva, R. Multiscale seismic vulnerability assessment and retrofit of existing masonry buildings. Buildings 2019, 9, 91. [CrossRef]

48. Fumo, M.; Formisano, A.; Sibilio, G.; Violano, A. Energy and seismic recovering of ancient hamlets: The case of Baia e Latina. Sustainability 2018, 10, 2831. [CrossRef]

49. Mongelli, M.; Bellagamba, I.; Iannone, F.; Bracco, G. From 2D digital imaging to finite element analysis using the ENEAGRID high performance computing infrastructure for the preservation of historical masonry structures. Int. J. Mason. Res. Innov. 2018, 3, 324-347. [CrossRef]

50. Valluzzi, M.R.; Calò, S.; Giacometti, G. Correlation of vulnerability and damage between artistic assets and structural elements: The DataBAES archive for the conservation planning of $\mathrm{CH}$ masonry buildings in seismic areas. Sustainability 2020, 12, 653. [CrossRef]

51. Barsocchi, P.; Bartoli, G.; Betti, M.; Girardi, M.; Mammolito, S.; Pellegrini, D.; Zini, G. Wireless Sensor Networks for Continuous Structural Health Monitoring of Historic Masonry Towers. Int. J. Archit. Herit. 2020, 14, 1-23. [CrossRef]

52. Marzouk, M. Using 3D laser scanning to analyze heritage structures: The case study of egyptian palace. J. Civil. Eng. Manag. 2020, 26, 53-65. [CrossRef]

53. Papa, E.; Taliercio, A. Creep modelling of masonry historic towers. In WIT Transactions on the Built Environment; WIT Press: Southampton, UK, 2003; Volume 66, pp. 131-140.

54. Roselli, I.; Malena, M.; Mongelli, M.; Cavalagli, N.; Gioffrè, M.; De Canio, G.; de Felice, G. Health assessment and ambient vibration testing of the "Ponte delle Torri" of Spoleto during the 2016-2017 Central Italy seismic sequence. J. Civ. Struct. Health Monit. 2018, 8, 199-216. [CrossRef]

55. Costa, C.; Arduin, D.; Rocha, F.; Velosa, A. Adobe Blocks in the Center of Portugal: Main Characteristics. Int. J. Archit. Herit. 2019, 13,1-12. [CrossRef]

56. Freire, M.T.; Veiga, M.d.R.; Santos Silva, A.; Brito, J.d. Studies in ancient gypsum based plasters towards their repair: Physical and mechanical properties. Constr. Build. Mater. 2019, 202, 319-331. [CrossRef]

57. Matias, G.; Faria, P.; Torres, I. Lime mortars with ceramic wastes: Characterization of components and their influence on the mechanical behaviour. Constr. Build. Mater. 2014, 73, 523-534. [CrossRef]

58. Sáez-Pérez, M.P.; Durán-Suárez, J.A.; Brummer, M. Hemp concrete for the sustainable retrofit of the vernacular architectural heritage in the region of Senhaja Srair (Morocco). In Conserving Cultural Heritage; Taylor \& Francis Group: London, UK, 2018; pp. 41-43.

59. Yokoyama, M.; Gril, J.; Matsuo, M.; Yano, H.; Sugiyama, J.; Clair, B.; Kubodera, S.; Mistutani, T.; Sakamoto, M.; Ozaki, H.; et al. Mechanical characteristics of aged Hinoki wood from Japanese historical buildings. C. R. Phys. 2009, 10, 601-611. [CrossRef]

60. Balaguer, L.; Mileto, C.; Vegas López-Manzanares, F.; García-Soriano, L. Bioclimatic strategies of traditional earthen architecture. J. Cult. Herit. Manag. Sustain. Dev. 2019, 9, 227-246. [CrossRef]

61. Hanie, O.; Nina, A.; Mohammad, R.B. A research on historical and cultural buildings in Iranian vernacular architecture. Archit. City Environ. 2011, VI, 37-57.

62. Carranza, J.B.; Lanzarote, B.S.; Madrigal, L.O.; Francés, L.S. Strategies for energy retrofitting of vernacular architecture of Cabanyal-Canyamelar. In Vernacular Architecture: Towards a Sustainable Future; Mileto, C., Vegas, F., Garcia Soriano, L., Cristini, V., Eds.; Taylor \& Francis Group: London, UK, 2014; pp. 135-141.

63. D'Aprile, M.; Bicco, M.; Gambardella, C.; Gambardella, C. The energy-environmental behavior of the pre-industrial basic building: Learning approach and applications. In Less More Architecture Design Landscape; La Scuola di Pitagora: Napoli, Italy, 2012; Volume 16, pp. 430-439. 
64. Musso, S.F.; Franco, G. "Guidelines" for sustainable rehabilitation of the rural architecture. In Vernacular Architecture: Towards a Sustainable Future; CRC Press: Boca Raton, FL, USA, 2014; pp. 531-536.

65. Roberti, F.; Exner, D.; Troi, A. Energy Consumption and Indoor Comfort in Historic Refurbished and Non-Refurbished Buildings in South Tyrol: An Open Database. In Proceedings of the International conference on Smart and Sustainable Planning for Cities and Regions, Bolzano, Italy, 9-13 December 2018; Springer: Bolzano, Italy, 2018; pp. 49-63.

66. Biseniece, E.; Žogla, G.; Kamenders, A.; Purviňš, R.; Kašs, K.; Vanaga, R.; Blumberga, A. Thermal performance of internally insulated historic brick building in cold climate: A long term case study. Energy Build. 2017, 152, 577-586. [CrossRef]

67. Hamard, E.; Cazacliu, B.; Razakamanantsoa, A.; Morel, J.-C. Cob, a vernacular earth construction process in the context of modern sustainable building. Build. Environ. 2016, 106, 103-119. [CrossRef]

68. Litti, G.; Khoshdel, S.; Audenaert, A.; Braet, J. Hygrothermal performance evaluation of traditional brick masonry in historic buildings. Energy Build. 2015, 105, 393-411. [CrossRef]

69. Sahin, C.D.; Coşkun, T.; Arsan, Z.D.; Gökçen Akkurt, G. Investigation of indoor microclimate of historic libraries for preventive conservation of manuscripts. Case Study: Tire Necip Paşa Library, İzmir-Turkey. Sustain. Cities Soc. 2017, 30, 66-78. [CrossRef]

70. Clark, G.; Leclerc, M.; Parton, P.; Reepmeyer, C.; Grono, E.; Burley, D. Royal funerals, ritual stones and participatory networks in the maritime Tongan state. J. Anthropol. Archaeol. 2020, 57, 101115. [CrossRef]

71. Mutani, G.; Todeschi, V.; Kampf, J.; Coors, V.; Fitzky, M. Building energy consumption modeling at urban scale: Three case studies in Europe for residential buildings. In Proceedings of the IEEE International Telecommunications Energy Conference, Torino, Italy, 7-11 October 2018.

72. Galvin, R.; Sunikka-Blank, M. Ten questions concerning sustainable domestic thermal retrofit policy research. Build. Environ. 2017, 118, 377-388. [CrossRef]

73. Goldberg, J.A.; Marshall, N.; Birtles, A.; Case, P.; Bohensky, E.; Curnock, M.; Gooch, M.; Parry-Husbands, H.; Pert, P.; Tobin, R. Climate change, the Great Barrier Reef and the response of Australians. Palgrave Commun. 2016, 2, 1-8. [CrossRef]

74. Nian, S.; Zhang, H.H.; Mao, L.; Zhao, W.; Zhang, H.H.; Lu, Y.; Zhang, Y.; Xu, Y. How Outstanding Universal Value, service quality and place attachment influences tourist intention towardsworld heritage conservation: A case study of Mount Sanqingshan National Park, China. Sustainability 2019, 11, 3321. [CrossRef]

75. Ramkissoon, H.; Uysal, M.S. The effects of perceived authenticity, information search behaviour, motivation and destination imagery on cultural behavioural intentions of tourists. Curr. Issues Tour. 2011, 14, 537-562. [CrossRef]

76. Ramkissoon, H. Authenticity, satisfaction, and place attachment: A conceptual framework for cultural tourism in African island economies. Dev. South. Afr. 2015, 32, 292-302. [CrossRef]

77. Bergel, M.; Brock, C. Visitors' loyalty and price perceptions: The role of customer engagement. Serv. Ind. J. 2019, 39, 575-589. [CrossRef]

78. Kim, M.-S.; Thapa, B.; Kim, H. International Tourists' Perceived Sustainability of Jeju Island, South Korea. Sustainability 2018, 10, 73. [CrossRef]

79. Piramanayagam, S.; Rathore, S.; Seal, P.P. Destination image, visitor experience, and behavioural intention at heritage centre. Anatolia 2020, 31, 211-228. [CrossRef]

80. Zhang, Y.; Wang, L. Influence of sustainable development by tourists' place emotion: Analysis of the multiply mediating effect of attitude. Sustainability 2019, 11, 1384. [CrossRef]

81. Megeirhi, H.A.; Woosnam, K.M.; Ribeiro, M.A.; Ramkissoon, H.; Denley, T.J. Employing a value-belief-norm framework to gauge Carthage residents' intentions to support sustainable cultural heritage tourism. J. Sustain. Tour. 2020, 28, 1351-1370. [CrossRef]

82. Yuan, Q.; Song, H.J.; Chen, N.; Shang, W. Roles of tourism involvement and place attachment in determining residents' attitudes toward industrial heritage tourism in a resource-exhausted city in China. Sustainability 2019, 11, 5151. [CrossRef]

83. Wang, C.; Li, G.; Xu, H. Impact of Lifestyle-Oriented Motivation on Small Tourism Enterprises' Social Responsibility and Performance. J. Travel Res. 2019, 58, 114-1160. [CrossRef]

84. Salvatierra, J.; Walters, G. The impact of human-induced environmental destruction on destination image perception and travel behaviour: The case of Australia's Great Barrier Reef. J. Vacat. Mark. 2015, 23, 73-84. [CrossRef] 
85. Wells, V.K.; Manika, D.; Gregory-Smith, D.; Taheri, B.; McCowlen, C. Heritage tourism, CSR and the role of employee environmental behaviour. Tour. Manag. 2015, 48, 399-413. [CrossRef]

86. Gregory-Smith, D.; Wells, V.K.; Manika, D.; McElroy, D.J. An environmental social marketing intervention in cultural heritage tourism: A realist evaluation. J. Sustain. Tour. 2017, 25, 1042-1059. [CrossRef]

87. Weiler, B.; Moyle, B.D.; Wolf, I.D.; de Bie, K.; Torland, M. Assessing the Efficacy of Communication Interventions for Shifting Public Perceptions of Park Benefits. J. Travel Res. 2017, 56, 468-481. [CrossRef]

88. Lee, S.; Phau, I. Young tourists' perceptions of authenticity, perceived value and satisfaction: The case of Little India, Singapore. Young Consum. 2018, 19, 70-86. [CrossRef]

89. Martin, J.C.; Marrero-Rodríguez, J.R.; Moreira, P.; Roman, C.; Santana, A. How access transport mode to a World Heritage City affects visitors' experienced quality. Tour. Econ. 2016, 22, 207-226. [CrossRef]

90. Valentina, V.; Marius-Răzvan, S.; Login, I.-A.; Anca, C. Changes in cultural heritage consumption model: Challenges and Limits. Procedia Soc. Behav. Sci. 2015, 188, 42-52. [CrossRef]

91. Muñoz-Fernández, G.A.; López-Guzmán, T.; López Molina, D.; Pérez Gálvez, J.C. Heritage tourism in the Andes: The case of Cuenca, Ecuador. Anatolia 2018, 29, 326-336. [CrossRef]

92. Cong, L.; Zhang, Y.; Su, C.-H.J.; Chen, M.-H.; Wang, J. Understanding Tourists' Willingness-to-Pay for Rural Landscape Improvement and Preference Heterogeneity. Sustainability 2019, 11, 7001. [CrossRef]

93. Dragouni, M.; Fouseki, K. Drivers of community participation in heritage tourism planning: An empirical investigation. J. Herit. Tour. 2018, 13, 237-256. [CrossRef]

94. Farr, M.; Stoeckl, N.; Esparon, M.; Larson, S.; Jarvis, D. The importance of water clarity to Great Barrier Reef tourists and their willingness to pay to improve it. Tour. Econ. 2016, 22, 331-352. [CrossRef]

95. Jin, M.; Juan, Y.; Choi, Y.; Lee, C.-K. Estimating the preservation value of world heritage site using contingent valuation method: The case of the Li River, China. Sustainability 2019, 11, 1100. [CrossRef]

96. Jurado-Rivas, C.; Sánchez-Rivero, M. Willingness to Pay for More Sustainable Tourism Destinations in World Heritage Cities: The Case of Caceres, Spain. Sustainability 2019, 11, 5880. [CrossRef]

97. Brida, J.G.; Meleddu, M.; Pulina, M. Understanding museum visitors' experience: A comparative study. J. Cult. Herit. Manag. Sustain. Dev. 2016, 6, 47-71. [CrossRef]

98. Di Pietro, L.; Mugion, R.G.; Mattia, G.; Renzi, M.F. Cultural heritage and consumer behaviour: A survey on Italian cultural visitors. J. Cult. Herit. Manag. Sustain. Dev. 2015, 5, 61-81. [CrossRef]

99. Gálvez, J.C.P.; Granda, M.J.; López-Guzmán, T.; Coronel, J.R. Local gastronomy, culture and tourism sustainable cities: The behavior of the American tourist. Sustain. Cities Soc. 2017, 32, 604-612. [CrossRef]

100. Kastenholz, E.; Eusébio, C.; Carneiro, M.J. Segmenting the rural tourist market by sustainable travel behaviour: Insights from village visitors in Portugal. J. Dest. Mark. Manag. 2018, 10, 132-142. [CrossRef]

101. Menor-Campos, A.; Pérez-Gálvez, J.C.; Hidalgo-Fernández, A.; López-Guzmán, T. Foreign Tourists in World Heritage Sites: A Motivation-Based Segmentation. Sustainability 2020, 12, 3263. [CrossRef]

102. Adie, B.A.; Hall, C.M.; Prayag, G. World Heritage as a placebo brand: A comparative analysis of three sites and marketing implications. J. Sustain. Tour. 2018, 26, 399-415. [CrossRef]

103. Gao, J.; Zhang, C.; Huang, Z. Chinese tourists' views of nature and natural landscape interpretation: A generational perspective. J. Sustain. Tour. 2018, 26, 668-684. [CrossRef]

104. Gao, J.; Huang, Z.; Zhang, C. Tourists' perceptions of responsibility: An application of norm-activation theory. J. Sustain. Tour. 2017, 25, 276-291. [CrossRef]

105. Wolf, I.D.; Stricker, H.K.; Hagenloh, G. Outcome-focused national park experience management: Transforming participants, promoting social well-being, and fostering place attachment. J. Sustain. Tour. 2015, 23, 358-381. [CrossRef]

106. Barton, J.; Hine, R.; Pretty, J. The health benefits of walking in greenspaces of high natural and heritage value. J. Integr. Environ. Sci. 2009, 6, 261-278. [CrossRef]

107. Huang, K.; Pearce, P.L.; Wu, M.-Y.; Wang, X.-Z. Tourists and Buddhist heritage sites: An integrative analysis of visitors' experience and happiness through positive psychology constructs. Tour. Stud. 2019, 19, 549-568. [CrossRef]

108. Lin, Y.C.; Liu, Y.C. Deconstructing the internal structure of perceived authenticity for heritage tourism. J. Sustain. Tour. 2018, 26, 2134-2152. [CrossRef]

109. Rani, Z.M.; Othman, N.; Ahmad, K.N. The Role of Perceived Authenticity as the Determinant to Revisit Heritage Tourism Destination in Penang. In Theory and Practice in Hospitality and Tourism Research, Penang, Malaysia, 2014; CRC Press: Penang, Malaysia, 2014; p. 293. 
110. Kunasegaran, M.; Rasoolimanesh, S.M.; Khan, S.K. Experiences of international tourists with healthy signature foods: A case study in Malacca. Br. Food J. 2019, 122, 1869-1882. [CrossRef]

111. Romão, J.; Neuts, B.; Nijkamp, P.; Shikida, A. Determinants of trip choice, satisfaction and loyalty in an eco-tourism destination: A modelling study on the Shiretoko Peninsula, Japan. Ecol. Econ. 2014, 107, 195-205. [CrossRef]

112. Ramkissoon, H.; Uysal, M. Testing the role of authenticity in cultural tourism consumption: A case of Mauritius. Tour. Anal. 2010, 15, 571-583. [CrossRef]

113. Bae, S.; Jung, T.H.; Moorhouse, N.; Suh, M.; Kwon, O. The Influence of Mixed Reality on Satisfaction and Brand Loyalty in Cultural Heritage Attractions: A Brand Equity Perspective. Sustainability 2020, 12, 2956. [CrossRef]

114. Cappa, F.; Rosso, F.; Capaldo, A. Visitor-Sensing: Involving the Crowd in Cultural Heritage Organizations. Sustainability 2020, 12, 1445. [CrossRef]

115. Chow, A.S.Y.; Ma, A.T.H.; Wong, G.K.L.; Lam, T.W.L.; Cheung, L.T.O. The impacts of place attachment on environmentally responsible behavioral intention and satisfaction of Chinese nature-based tourists. Sustainability 2019, 11, 5585. [CrossRef]

116. Curnock, M.I.; Marshall, N.A.; Thiault, L.; Heron, S.F.; Hoey, J.; Williams, G.; Taylor, B.; Pert, P.L.; Goldberg, J.A. Shifts in tourists' sentiments and climate risk perceptions following mass coral bleaching of the Great Barrier Reef. Nat. Clim. Chang. 2019, 9, 535-541. [CrossRef]

117. Khairi, N.D.; Ismail, H.N.; Syed Jaafar, S.M.R. Tourist behaviour through consumption in Melaka world heritage site. Curr. Issues Tour. 2019, 22, 582-600. [CrossRef]

118. Medina-Viruel, M.J.; López-Guzmán, T.; Gálvez, J.C.P.; Jara-Alba, C. Emotional perception and tourist satisfaction in world heritage cities: The Renaissance monumental site of úbeda and baeza, Spain. J. Outdoor Recreat. Tour. 2019, 27, 100226. [CrossRef]

119. Weber, M.; Groulx, M.; Lemieux, C.J.; Scott, D.; Dawson, J. Balancing the dual mandate of conservation and visitor use at a Canadian world heritage site in an era of rapid climate change. J. Sustain. Tour. 2019, 27, 1318-1337. [CrossRef]

120. Woyo, E.; Woyo, E. Towards the development of cultural tourism as an alternative for tourism growth in Northern Zimbabwe. J. Cult. Herit. Manag. Sustain. Dev. 2019, 9, 74-92. [CrossRef]

121. Wu, D.; Shen, C.; Wang, E.; Hou, Y.; Yang, J. Impact of the perceived authenticity of heritage sites on subjective well-being: A study of the mediating role of place attachment and satisfaction. Sustainability 2019, 11, 6148. [CrossRef]

122. Scuttari, A.; Orsi, F.; Bassani, R. Assessing the tourism-traffic paradox in mountain destinations. A stated preference survey on the Dolomites' passes (Italy). J. Sustain. Tour. 2019, 27, 241-257. [CrossRef]

123. Alazaizeh, M.M.; Jamaliah, M.M.; Mgonja, J.T.; Ababneh, A. Tour guide performance and sustainable visitor behavior at cultural heritage sites. J. Sustain. Tour. 2019, 27, 1708-1724. [CrossRef]

124. Song, H.; Kim, H. Value-based profiles of visitors to a world heritage site: The case of Suwon Hwaseong fortress (in South Korea). Sustainability 2019, 11, 132. [CrossRef]

125. Borges, A.P.; Vieira, E.P.; Gomes, S. The Expenditure Behaviour during the Trip and the Impact of the Intangible and Tangible Factors: The Case of the City of Porto. In 32nd International Business Information Management Association, Sevilla, Spain, 2018; IBIMA: Sevilla, Spain, 2018; pp. 5948-5957.

126. Cheng, T.E.; Wang, J.; Cao, M.M.; Zhang, D.J.; Bai, H.X. The relationships among interpretive service quality, satisfaction, place attachment and environmentally responsible behavior at the cultural heritage sites in Xi'an, China. Appl. Ecol. Environ. Res. 2018, 16, 6317-6339. [CrossRef]

127. Mehmood, S.; Liang, C.; Gu, D. Heritage Image and Attitudes toward a Heritage Site: Do They Really Mediate the Relationship between User-Generated Content and Travel Intentions toward a Heritage Site? Sustainability 2018, 10, 4403. [CrossRef]

128. Prayag, G.; Suntikul, W.; Agyeiwaah, E. Domestic tourists to Elmina Castle, Ghana: Motivation, tourism impacts, place attachment, and satisfaction. J. Sustain. Tour. 2018, 26, 2053-2070. [CrossRef]

129. Martinez-Garcia, E.; Raya-Vilchez, J.M.; Galí, N. Factors Affecting Time Spent Visiting Heritage City Areas. Sustainability 2018, 10, 1824. [CrossRef]

130. Weaver, D.; Tang, C.; Shi, F.; Huang, M.-F.; Burns, K.; Sheng, A. Dark tourism, emotions, and postexperience visitor effects in a sensitive geopolitical context: A Chinese case study. J. Travel Res. 2018, 57, 824-838. [CrossRef] 
131. Wang, B.; Yang, Z.; Han, F.; Shi, H. Car tourism in Xinjiang: The mediation effect of perceived value and tourist satisfaction on the relationship between destination image and loyalty. Sustainability 2017, 9, 22. [CrossRef]

132. Su, L.; Hsu, M.K.; Swanson, S. The effect of tourist relationship perception on destination loyalty at a world heritage site in China: The mediating role of overall destination satisfaction and trust. J. Hosp. Tour. Res. 2017, 41, 180-210. [CrossRef]

133. Soliman, M.S.A.; Abou-Shouk, M.A. Predicting Behavioural Intention of International Tourists Towards Geotours. Geoheritage 2017, 9, 505-517. [CrossRef]

134. Trivedi, A. Towards Sustainable Tourism in Thailand: Example of Tourists' Implementation at Heritage Destinations. In Proceedings of the 3rd RSEP International Conference on Social Issues and Economic Studies, Vienna, Austria, 5-7 April 2017; pp. 5-7.

135. Buonincontri, P.; Marasco, A.; Ramkissoon, H. Visitors' experience, place attachment and sustainable behaviour at cultural heritage sites: A conceptual framework. Sustainability 2017, 9, 1112. [CrossRef]

136. Brida, J.G.; Dalle Nogare, C.; Scuderi, R. Frequency of museum attendance: Motivation matters. J. Cult. Econ. 2016, 40, 261-283. [CrossRef]

137. Getzner, M.; Färber, B.; Yamu, C. 2D Versus 3D: The relevance of the mode of presentation for the economic valuation of an Alpine landscape. Sustainability 2016, 8, 591. [CrossRef]

138. Lee, S.; Phau, I.; Hughes, M.; Li, Y.F.; Quintal, V. Heritage tourism in Singapore Chinatown: A perceived value approach to authenticity and satisfaction. J. Travel Tour. Mark. 2016, 33, 981-998. [CrossRef]

139. Sabou, G.C.; Nistoreanu, P.; Maiorescu, I. Modelling urban economic development through heritage touristm spatial analysis. In Proceedings of the BASIQ International Conference: New Trends in Sustainable Business and Consumption, Kontantz, Germany, 2-3 June 2016.

140. Khairi, N.D.M.; Ismail, H.N. Acknowledging the Tourist Spatial Behavior for Space Management in Urban Heritage Destination. Int. J. Sustain. Built Environ. 2015, 2, 317-323. [CrossRef]

141. Mustafa, M.H. Gender and behavior in archaeological sites. Int. J. Hosp. Tour. Adm. 2015, 16, 183-201. [CrossRef]

142. Huang, S.; Weiler, B.; Assaker, G. Effects of Interpretive Guiding Outcomes on Tourist Satisfaction and Behavioral Intention. J. Travel Res. 2015, 54, 344-358. [CrossRef]

143. Toha, M.A.M.; Ismail, H.N. A heritage tourism and tourist flow pattern: A perspective on traditional versus modern technologies in tracking the tourists. Int. J. Sustain. Built Environ. 2015, 2, 85-92.

144. Ballantyne, R.; Hughes, K.; Ding, P.; Liu, D. Chinese and international visitor perceptions of interpretation at Beijing built heritage sites. J. Sustain. Tour. 2014, 22, 705-725. [CrossRef]

145. Jones, T.; Yamamoto, K. Comparing the Awareness of a New Donation System and Willingness to Pay of Japanese and International Climbers at Mount Fuji. In Proceedings of the 4th International Conference on Tourism Research (4ICTR), EDP Sciences: Sabah, Malaysia, 9-11 December 2014; p. 1090.

146. King, L.M.; Halpenny, E.A. Communicating the World Heritage brand: Visitor awareness of UNESCO's World Heritage symbol and the implications for sites, stakeholders and sustainable management. J. Sustain. Tour. 2014, 22, 768-786. [CrossRef]

147. Bernadó, O.; Bigorra, A.; Pérez, Y.; Russo, A.P.; Clave, S.A. Analysis of tourist behavior based on tracking data collected by GPS. In Geographic Information Systems: Concepts, Methodologies, Tools, and Applications; IGI Global: Hershey, PA, USA, 2013; pp. 1100-1119.

148. Li, J.H.; Sia, R.; Zhu, Y.B. Research on Cultural Heritage Tourism Development Based on Tourist Perception: Taking Beijing Olympic Park of China as an Example. Appl. Mech. Mater. 2013, 361-363, 21-26. [CrossRef]

149. Wallace, A. Presenting Pompeii: Steps towards reconciling conservation and tourism at an ancient site. Papers Inst. Archaeol. 2013, 22, 115. [CrossRef]

150. Ramkissoon, H.; Smith, L.D.G.; Weiler, B. Relationships between place attachment, place satisfaction and pro-environmental behaviour in an Australian national park. J. Sustain. Tour. 2013, 21, 434-457. [CrossRef]

151. Boukas, N. "Young faces in old places": Perceptions of young cultural visitors for the archaeological site of Delphi. J. Cult. Herit. Manag. Sustain. Dev. 2012, 2, 164-189. [CrossRef]

152. Yang, M.; Hens, L.; De Wulf, R.; Ou, X. Measuring tourist's water footprint in a mountain destination of Northwest Yunnan, China. J. Mt. Sci. 2011, 8, 682. [CrossRef]

153. Boley, B.B.; Nickerson, N.P.; Bosak, K. Measuring geotourism: Developing and testing the geotraveler tendency scale (GTS). J. Travel Res. 2011, 50, 567-578. [CrossRef]

154. McNamara, K.E.; Prideaux, B. Reading, learning and enacting: Interpretation at visitor sites in the Wet Tropics rainforest of Australia. Environ. Educ. Res. 2010, 16, 173-188. [CrossRef] 
155. Weiler, B.; Ham, S.H. Development of a research instrument for evaluating the visitor outcomes of face-to-face interpretation. Visit. Stud. 2010, 13, 187-205. [CrossRef]

156. McKercher, B.; Weber, K.; Du Cros, H. Rationalising inappropriate behaviour at contested sites. J. Sustain. Tour. 2008, 16, 369-385. [CrossRef]

157. Cooper, M. Backpackers to Fraser Island: Why Is Ecotourism a Neglected Aspect aof Their Experience? J. Qual. Assur. Hosp. Tour. 2000, 1, 45-59. [CrossRef]

158. Fellenius, K.; Williams, P.W.; Hood, T. Emerging Coastal Tourism Potential in British Columbia: The Fisheries Tourism Network and the German Market; World Congress on Coastal and Marine Tourism: Vancouver, BC, Canada, 1999.

159. Suryawardani, I.G.A.O.; Wiranatha, A.S.; Petr, C. Factors affecting willingness of foreign tourists to spend money in benefiting local people. In Development of Tourism and the Hospitality Industry in Southeast Asia; Springer: Singapore, 2016; pp. 13-36.

160. Hidalgo-Fernández, A.; Hernández-Rojas, R.; Jimber del Río, J.A.; Casas-Rosal, J.C. Tourist Motivations and Satisfaction in the Archaeological Ensemble of Madinat Al-Zahra. Sustainability 2019, 11, 1380. [CrossRef]

161. Chong, K.L. The side effects of mass tourism: The voices of Bali islanders. Asia Pacific J. Tour. Res. 2020, 25, 157-169. [CrossRef]

162. Gannon, M.; Rasoolimanesh, S.M.; Taheri, B. Assessing the mediating role of residents' perceptions toward tourism development. J. Travel Res. 2020, 59, 1-23. [CrossRef]

163. Zheng, D.; Liang, Z.; Ritchie, B.W. Residents' social dilemma in sustainable heritage tourism: The role of social emotion, efficacy beliefs and temporal concerns. J. Sustain. Tour. 2020, 28, 1-23. [CrossRef]

164. Cai, Z.; Lu, M. Social Integration Measurement of Inhabitants in Historic Blocks: The Case of Harbin, China. Sustainability 2018, 10, 2825. [CrossRef]

165. Judson, E.P.; Iyer-Raniga, U.; Horne, R. Greening heritage housing: Understanding homeowners' renovation practices in Australia. J. Hous. Built Environ. 2014, 29, 61-78. [CrossRef]

166. Su, X.; Li, X.; Wu, Y.; Yao, L. How Is Intangible Cultural Heritage Valued in the Eyes of Inheritors? Scale Development and Validation. J. Hosp. Tour. Res. 2020, 44, 806-834. [CrossRef]

167. Yuan, Z.; Lun, F.; He, L.; Cao, Z.; Min, Q.; Bai, Y.; Liu, M.; Cheng, S.; Li, W.; Fuller, A.M. Exploring the state of retention of traditional ecological knowledge (TEK) in a Hani rice terrace village, Southwest China. Sustainability 2014, 6, 4497-4513. [CrossRef]

168. Qiu, Q.; Zheng, T.; Xiang, Z.; Zhang, M. Visiting Intangible Cultural Heritage Tourism Sites: From Value Cognition to Attitude and Intention. Sustainability 2020, 12, 132. [CrossRef]

169. Olya, H.G.T.; Shahmirzdi, E.K.; Alipour, H. Pro-tourism and anti-tourism community groups at a world heritage site in Turkey. Curr. Issues Tour. 2019, 22, 763-785. [CrossRef]

170. Prados-Peña, M.B.; Gutiérrez-Carrillo, M.L.; Barrio-García, D. The development of loyalty to earthen defensive heritage as a key factor in sustainable preventive conservation. Sustainability 2019, 11, 3516. [CrossRef]

171. Davoodi, T.; Dağlı, U.U. Exploring the Determinants of Residential Satisfaction in Historic Urban Quarters: Towards Sustainability of the Walled City Famagusta, North Cyprus. Sustainability 2019, 11, 6261. [CrossRef]

172. Gursoy, D.; Zhang, C.; Chi, O.H. Determinants of locals' heritage resource protection and conservation responsibility behaviors. Int. J. Contemp. Hosp. Manag. 2019, 31, 2339-2357. [CrossRef]

173. Zhang, Y.; Lee, T.J.; Xiong, Y. A conflict resolution model for sustainable heritage tourism. Int. J. Tour. Res. 2019, 21, 478-492. [CrossRef]

174. Zhang, Y.; Xiao, X.; Zheng, C.; Xue, L.; Guo, Y.; Wu, Q. Is tourism participation in protected areas the best livelihood strategy from the perspective of community development and environmental protection? J. Sustain. Tour. 2019, 28, 587-605. [CrossRef]

175. Chen, Y.; Yang, J. The Chinese Socio-Cultural Sustainability Approach: The Impact of Conservation Planning on Local Population and Residential Mobility. Sustainability 2018, 10, 4195. [CrossRef]

176. López, M.F.B.; Virto, N.R.; Manzano, J.A.; Miranda, J.G.-M. Residents' attitude as determinant of tourism sustainability: The case of Trujillo. J. Hosp. Tour. Manag. 2018, 35, 36-45. [CrossRef]

177. Yasin, M.N.B.; Abdullah, A.H.B.; Ibrahim, M.H.B.W.; Khalid, H.B.A.; Wahab, N.S.N.B. A Study of Potential Retroffiting Existing Sultan Ibrahim Heritage Building to Green Building. Adv. Sci. Lett. 2018, 24, 3213-3216. [CrossRef]

178. Goldberg, J.A.; Marshall, N.A.; Birtles, A.; Case, P.; Curnock, M.I.; Gurney, G.G. On the relationship between attitudes and environmental behaviors of key Great Barrier Reef user groups. Ecol. Soc. 2018, 23, 19. [CrossRef] 
179. Domic, D.; Boukas, N. Identifying Croatian museums' indigenous visitors in a post-war era: Perceptual examinations of one's own heritage. J. Tour. Cult. Chang. 2017, 15, 229-247. [CrossRef]

180. Wang, W.; Zhang, Y.; Han, J.; Liang, P. Developing teenagers' role consciousness as "world heritage guardians". J. Cult. Herit. Manag. Sustain. Dev. 2017, 7, 179-192. [CrossRef]

181. Esariti, L.; Yuliastuti, N.; Ratih, N.K. Riverine settlement adaptation characteristic in Mentaya River, East Kotawaringin Regency, Kalimantan Province. In Proceedings of the 2nd Geoplanning-International Conference on Geomatics and Planning, Surakarta, Indonesia, 9-10 August 2017; pp. 1-9.

182. Rodzi, N.I.M.; Zaki, S.A.; Subli, S.M.H.S. Influence of Social Behaviors toward Cultural Heritage Sustainability in World Heritage Site, Melaka. Environ. Behav. 2016, 1, 217-225.

183. Basarić, V.; Vujičić, A.; Simić, J.M.; Bogdanović, V.; Saulić, N. Gender and age differences in the travel behavior-a Novi Sad case study. Transp. Res. Procedia 2016, 14, 4324-4333. [CrossRef]

184. Lwoga, N.B. Tourism employment and local residents' engagement in the conservation of the built heritage in Zanzibar Stone Town in Tanzania. Wit Trans. Ecol. Environ. 2016, 201, 43-55.

185. May-Chiun, L.; Peter Songanc, V.N. Rural tourism destination competitiveness: A study on Annah Rais Longhouse Homestay, Sarawak. Procedia Soc. Behav. Sci. 2014, 144, 35-44. [CrossRef]

186. Bosman, G.; Whitfield, C. Perceptions of vernacular architecture. In Vernacular Architecture: Towards a Sustainable Future; CRC Press: Boca Raton, FL, USA, 2014; pp. 177-182.

187. Omar, S.I.; Muhibudin, M.; Yussof, I.; Sukiman, M.F.; Mohamed, B. George Town, Penang as a world heritage site: The stakeholders' perceptions. Procedia Soc. Behav. Sci. 2013, 91, 88-96. [CrossRef]

188. Yunus, R.M.; Karim, S.A.; Samadi, Z. Gateway to Sustainable National Park. Procedia Soc. Behav. Sci. 2013, 85, 296-307. [CrossRef]

189. Ma, Y.W.; Zhao, Y.T.; Gong, H.D. Community residents' eco-environment protection awareness in the Jiajin Mountains Giant Panda Sanctuary. Adv. Mat. Res. 2013, 610-613, 3257-3262. [CrossRef]

190. Ryan, C.; Chaozhi, Z.; Zeng, D. The impacts of tourism at a UNESCO heritage site in China-a need for a meta-narrative? The case of the Kaiping Diaolou. J. Sustain. Tour. 2011, 19, 747-765. [CrossRef]

191. Nicholas, L.N.; Thapa, B.; Ko, Y.J. Residents'perspectives of a world heritage site: The Pitons Management Area, St. Lucia. Ann. Tour. Res. 2009, 36, 390-412. [CrossRef]

192. Senaratne, A.; Abeygunawardena, P.; Jayatilake, W. Changing role of non-timber forest products (NTFP) in rural household economy: The case of Sinharaja World Heritage site in Sri Lanka. Environ. Manag. 2003, 32, 559-571. [CrossRef]

193. Chi, C.G.-q.; Zhang, C.; Liu, Y. Determinants of corporate social responsibility (CSR) attitudes: Perspective of travel and tourism managers at world heritage sites. Int. J. Contemp. Hosp. Manag. 2019, 31, 2253-2269. [CrossRef]

194. Esparon, M.; Gyuris, E.; Stoeckl, N. Does ECO certification deliver benefits? An empirical investigation of visitors' perceptions of the importance of ECO certification's attributes and of operators' performance. J. Sustain. Tour. 2014, 22, 148-169. [CrossRef]

195. Choi, A.S.; Lee, C.-K.; Tanaka, K.; Xu, H. Value spillovers from the Korean DMZ areas and social desirability. J. Behav. Exp. Econ. 2018, 75, 95-104. [CrossRef]

196. Rose, M.; Rose, G.M.; Merchant, A. Is old gold? How heritage "sells" the university to prospective students: The impact of a measure of brand heritage on attitudes toward the university. J. Advert. Res. 2017, 57, 335-351. [CrossRef]

197. Forleo, M.B.; Romagnoli, L.; Palmieri, N. Environmental values and willingness to pay for a protected area: A segmentation of Italian university students. Int. J. Sustain. Dev. World Ecol. 2019, 26, 45-56. [CrossRef]

198. Ferretti, V.; Grosso, R. Designing successful urban regeneration strategies through a behavioral decision aiding approach. Cities 2019, 95, 102386. [CrossRef]

199. Mustafa, M.H. Tour guides and the protection of archaeological sites: A case from Jordan. Anatolia 2019, 30, 586-600. [CrossRef]

200. Zhang, L.; Zhang, J. Perception of small tourism enterprises in Lao PDR regarding social sustainability under the influence of social network. Tour. Manag. 2018, 69, 109-120. [CrossRef]

201. Väisänen, H.-M.; Törn-Laapio, A. Place Identity: Sustainability Performance Relationship among Rural Tourism Entrepreneurs; International Conference on Tourism Research, Academic Conferences and Publishing International Ltd.: Jyväskylä, Finland, 2018.

202. McCamley, C.; Gilmore, A. Aggravated fragmentation: A case study of SME behaviour in two emerging heritage tourism regions. Tour. Manag. 2017, 60, 81-91. [CrossRef] 
203. Abdulla, K.M.A.; Abdelmonem, M.G.; Selim, G. Walkability in Historic Urban Spaces: Testing the Safety and Security in Martyrs' Square in Tripoli. Archnet-Ijar 2017, 11, 163-177. [CrossRef]

204. Gribaudo, M.; Iacono, M.; Levis, A.H. An IoT-based monitoring approach for cultural heritage sites: The Matera case. Concurr. Comput. 2017, 29, e4153. [CrossRef]

205. Miralles i Garcia, J.L. Environ. Manage. of peri-urban natural resources: L'Horta de Valencia case study. Ecosyst. Sustain. Dev. X 2015, 1, 99-110.

206. Çetinkaya, M.Y.; Zafer, O. Sustainable valorization of cultural heritage via tour guides: Turkish case of Ephesus ancient city. PASOS Revista de Tur. y Patrim. Cult. 2015, 13, 1401-1412. [CrossRef]

207. Gheorghe, G.; Nistoreanu, B.G.; Filip, A. Traditional products-vectors of sustainable development on the regional and national markets. Amfiteatru Econ. 2013, 15, 6459-6658.

208. Hall, C.M. Why forage when you don't have to? Personal and cultural meaning in recreational foraging: A New Zealand study. J. Herit. Tour. 2013, 8, 224-233. [CrossRef]

209. Santos, T.; Mendes, R.N.; Rodrigues, A.M.; Freire, S. Treasure Hunting in the 21st century: A Decade of Geocaching in Portugal. In Proceedings of the 6th European Conference on Information Management and Evaluation, Cork, Ireland, 13-14 September 2012; pp. 273-281.

210. Wiedmann, K.-P.; Hennigs, N.; Schmidt, S.; Wuestefeld, T. Drivers and outcomes of brand heritage: consumers' perception of heritage brands in the automotive industry. J. Mark. Theory Pract. 2011, 19, 205-220. [CrossRef]

211. Thomas, S.; Miller, C.; Thomas, B.; Tunstall, R.; Siggins, N. Mastering intrapreneurial behaviour for sustained socioeconomic development: A public service analysis of the south-east Wales heritage tourism attractions sector. Int. J. Entrep. Innov. 2007, 8, 75-83. [CrossRef]

212. Marchegiani, L. From Mecenatism to crowdfunding: Engagement and identification in cultural-creative projects. J. Herit. Tour. 2018, 13, 143-151. [CrossRef]

213. Shi, X.; Si, B.; Zhao, J.; Tian, Z.; Wang, C.; Jin, X.; Zhou, X. Magnitude, causes, and solutions of the performance gap of buildings: A review. Sustainability 2019, 11, 937. [CrossRef]

214. Perovic, M.; Coffey, V.; Kajewski, S.; Madan, A. Unravelling heritage challenges: Three case studies. J. Cult. Herit. Manag. Sustain. Dev. 2016, 6, 330-344. [CrossRef]

215. Roy, D.; Kalidindi, S.N. Critical challenges in management of heritage conservation projects in India. J. Cult. Herit. Manag. Sustain. Dev. 2017, 7, 290-307. [CrossRef]

216. Gonçalves, J.; Mateus, R.; Silvestre, J.D. Mapping Professional Practice Challenges in Built Heritage; CRC Press: Boca Raton, FL, USA, 2019; p. 125.

217. Brás, A.; Valença, A.; Faria, P. Performance-based methods for masonry building rehabilitation using innovative leaching and hygrothermal risk analyses. Sustain. Cities Soc. 2017, 28, 321-331. [CrossRef]

218. Caro, R.; Sendra, J.J. Evaluation of indoor environment and energy performance of dwellings in heritage buildings. The case of hot summers in historic cities in Mediterranean Europe. Sustain. Cities Soc. 2020, 52, 101798. [CrossRef]

219. Galiano-Garrigós, A.; González-Avilés, Á.; Rizo-Maestre, C.; Andújar-Montoya, M.D. Energy Efficiency and Economic Viability as Decision Factors in the Rehabilitation of Historic Buildings. Sustainability 2019, 11, 4946. [CrossRef]

220. Love, P.; Bullen, P.A. Toward the sustainable adaptation of existing facilities. Facilities 2009, 27, 357-367. [CrossRef]

221. Berg, F; Donarelli, A. Energy Performance Certificates and Historic Apartment Buildings: A Method to Encourage User Participation and Sustainability in the Refurbishment Process. Hist. Environ. Policy Pract. 2019, 10, 224-240. [CrossRef]

222. Orbell, S.; Hodgkins, S.; Sheeran, P. Implementation intentions and the theory of planned behavior. Pers. Soc. Psychol. Bull. 1997, 23, 945. [CrossRef]

Publisher's Note: MDPI stays neutral with regard to jurisdictional claims in published maps and institutional affiliations. 